International Journal of Earth Sciences

Volume 96, Number 1 / February, 2007: P37-56

http://dx.doi.org/10.1007/s00531-006-0130-6

(C2007 Springer Science+Business Media
Archimer, archive institutionnelle de l'Ifremer http://www.ifremer.fr/docelec/

\title{
Morphology and environment of cold-water coral carbonate mounds on the NW European margin
}

\author{
A. J. Wheeler ${ }^{1, *}$ A. Beyer ${ }^{2}$, A. Freiwald ${ }^{3,}$ H. de Haas ${ }^{4}$, V. A. I. Huvenne ${ }^{5,6}$, M. Kozachenko ${ }^{1}$, \\ K. Olu-Le Roy ${ }^{7}$ and J. Opderbecke ${ }^{8}$
}

(1) Department of Geology and Environmental Research Institute, University College Cork, College Rd., Cork, Ireland

(2) Alfred Wegener Institute for Polar and Marine Research, Columbusstr., 27568 Bremerhaven, Germany

(3) Institute of Paleontology, University of Erlangen-Nuremberg, 91054 Erlangen, Germany

(4) Royal Netherlands Institute for Sea Research (NIOZ), PO Box 59, 1790, AB, Den Burg, The Netherlands

(5) Renard Centre of Marine Geology, University of Gent, Krijgslaan 281, S8, 9000 Gent, Belgium

(6) Present address: National Oceanography Centre, Southampton, European Way, Southampton, SO14 3ZH,

UK

(7) IFREMER, Centre de Brest, BP 70, 29280 Plouzané, France

(8) Navigation and Vision Department (RNV), Zone Portuaire de Brégaillon, IFREMER - Underwater Robotics, 83507 La Seyne-sur-mer, France

*: Corresponding author : a.wheeler@ucc.ie

\begin{abstract}
:
Cold-water coral carbonate mounds, owing their presence mainly to the framework building coral Lophelia pertusa and the activity of associated organisms, are common along the European margin with their spatial distribution allowing them to be divided into a number of mound provinces. Variation in mound attributes are explored via a series of case studies on mound provinces that have been the most intensely investigated: Belgica, Hovland, Pelagia, Logachev and Norwegian Mounds. Morphological variation between mound provinces is discussed under the premise that mound morphology is an expression of the environmental conditions under which mounds are initiated and grow. Cold-water coral carbonate mounds can be divided into those exhibiting "inherited" morphologies (where mound morphology reflects the morphology of the colonised features) and "developed" morphology (where the mounds assume their own gross morphology mainly reflecting dominant hydrodynamic controls). Finer-scale, surface morphological features mainly reflecting biological growth forms are also discussed.
\end{abstract}

Keywords: Carbonate mound - Cold-water coral - Morphology - Environmental setting - Seabed mapping 


\section{Introduction}

The cold-water coral Lophelia pertusa (L.) is widespread along the European continental margin (e.g. Le Danois, 1948; Teichert, 1958; Wilson, 1979a; Zibrowius, 1980; Frederiksen et al., 1992; Rogers, 1999; Freiwald et al., 2002; Taviani et al., 2005; Roberts et al., 2006) and is often associated, although not exclusively with cold-water coral carbonate mounds. Research and ecological status reports on cold-water coral has been reviewed by Rogers (1999) and more recently in Freiwald et al. (2004) and Roberts et al. (2006) although limited attention was paid in these reviews to their geological products: cold-water coral carbonate mounds. A brief, timely review of research on European examples is presented here for a selective number of mound provinces. Cold-water coral carbonate mounds in this context refer to positive topographic features that owe their origin, partially or entirely, to the framework-building capacity of cold-water corals and have also been referred to as reefs, banks, carbonate mounds and coral build-ups (see Freiwald, 2002) .

Cold-water coral carbonate mounds vary in size and shape ranging from small, low relief ovoid features a few metres high and tens of metres across (e.g. Wilson et al., 1979b; Scoffin et al., 1980; Masson et al., 2003; Foubert et al., 2005; Wheeler et al., 2005b; Wheeler et al., 2005c; Lindberg et al., this volume; Wheeler et al., subm.), to giant mounds hundreds of metres tall and a few kilometres across (e.g. Kenyon et al., 1998; De Mol et al., 2002; Huvenne et al., 2002; Akhmetzhanov, et al., 2003; Beyer et al., 2003; Huvenne et al., 2003; Kenyon et al., 2003, O’Reilly et al., 2003; van Weering et al., 2003; O'Reilly \& Readman, 2004; De Mol et al., 2005; Foubert et al., 2005; Wheeler et al., 2005c; Huvenne et al., 2005; Beyer et al., this volume; De Mol et al., this volume; Huvenne et al., this volume; Mienis et al., in press). The origin of these mounds has been related to hydrocarbon seepage (Hovland \& Thomsen, 1989; Hovland, 1990; Hovland, 1992; Hovland et al., 1994; Hovland \& Thomsen, 1997; Henriet et al., 1998; Hovland et al., 1998; Henriet et al., 2001; Hovland \& Risk, 2003) or autogenic processes stimulated by high current speeds and food supply (Frederiksen et al., 1992; Freiwald et al., 1997; Mortensen et al., 2001; De Mol et al., 2002; Kenyon et al., 2003; Duineveld et al., 2004; White et al., 2005). Despite these debates on mound genesis, little evidence exists for the hydrocarbon seepage model whereas recent evidence (Expedition Scientists, 2005) suggest that hydrodynamic conditions have a strong influence on mound growth and therefore resultant morphologies.

A significant increase in the extent of seabed mapping of the European continental margin in recent years has given rise to a more complete understanding of the location and variability of European cold-water coral carbonate mounds. Regional mapping exercises using low frequency side-scan sonars $(10-30 \mathrm{kHz})$ and deepwater multibeam systems have identified numerous mound-like features that have subsequently been confirmed as coral-colonised by video or seabed sampling (e.g. Unnithan, 2001; Masson et al., 2003; Beyer et al., 2003; O’Reilly et al., 2003; Fosså et al., 2005; Foubert et al., 2005; Huvenne et al., 2005; Wheeler et al., 2005a; Beyer et al., this volume; Huvenne et al., this volume; Mienis et al., in press). Furthermore, the discovery of many, often buried, cold-water coral carbonate mounds has occurred as a result of the expansion of hydrocarbon exploration activity along the European margin with cold-water coral carbonate mounds clearly revealed in seismic sections due to their topographic relief and a bright chaotic internal signature (e.g. De Mol et al., 2002; Henriet et al., 2003; Huvenne et al., 2003; Kenyon et al., 2003; van Weering et al., 2003; De Mol et al., 2005; Fosså et al., 2005; De Mol et al., this volume).

More targeted, high frequency side-scan sonar mapping surveys $(100-410 \mathrm{kHz})$ and ROV-mounted multibeam surveys have revealed details of gross and surface mound morphology (e.g. Kenyon et al., 1998; Freiwald et al., 1999; Freiwald et al., 2002; Olu-Le Roy et al., 2002; Akhmetzhanov et al., 2003; Kenyon et al., 2003; Fosså et al., 2005; Foubert et al., 2005; Wheeler et al., 2005a; Wheeler et al., 2005b; Wheeler et al., 2005c; De Mol et al, this volume; Lindberg et al., this volume). These images reveal that gross mound morphology is strongly influenced by the dominant current directions but may also be inherited from the morphology of features that provide the initial hard substrate facilitating settlement and early colonisation. Mound-surface texture may reflect either the nature of biological growth forms influenced by the sedimentary and hydrodynamic regime, or erosion.

The aim of this paper is to present an overview of morphological variation between different cold-water carbonate mounds based on extensive survey work over the past few years. This is achieved via a series of case studies where mounds are also set within their environmental context. As such, this paper presents limited new data although the timely review and synthesis is further discussed to elucidate the underlying factors controlling cold-water carbonate mound morphology from which a new mound morphological classification system is defined. 


\section{Distribution of Lophelia pertusa}

Cold-water coral carbonate mounds become elevated above the surrounding seabed due to the framework building and sediment baffling capacity of the corals; mainly Lophelia pertusa and Madrepora oculata. Lophelia exists in water temperatures ranging from $4-13^{\circ} \mathrm{C}$, can tolerate a range of salinity, is usually associated with oxygen minima (reflecting high concentrations of suspended organic material) and high current speeds (favourable for suspension feeding organisms). In European waters, such conditions occur down to a depth of c.1000 m (e.g. Rogers, 1999; Freiwald et al., 2004; Roberts et al., 2006).

Lophelia has a global distribution and is widespread along continental margins, seamounts and banks in intermediate and shallow water depths. Rogers (1999), Freiwald et al. (2004) and Roberts et al. (2006) present reviews of the literature on the biology of Lophelia and framework building cold-water corals respectively, thereby documenting published reports of occurrences worldwide. Figure 1 shows this global distribution based on a database generated by the Institute of Paleontology Erlangen, Germany, with counts of 2084 sites for Lophelia (live, dead, and fossil). This clearly demonstrates a concentration of Lophelia in the Atlantic and especially the NE Atlantic with 1816 documented occurrences (89\% of known occurrences)

Figure 2 shows that Lophelia is fairly evenly distributed along the European margin from the Gulf of Cadiz to northern Norway although two areas of limited Lophelia occurrences are noted: the northern French canyon systems and the eastern Rockall margin north of the Porcupine Bank. High Lophelia occurrences are also noted on the banks west of Ireland/UK and on the broad Norwegian Shelf. Many of these occurrences reflect isolated colonies that may be transient in nature whereas others are associated with giant cold-water coral carbonate mounds that have probably existed for a few million years. The giant mounds occur exclusively in the Porcupine Seabight, Porcupine Bank, Rockall Bank and Hatton Bank. Figure 2 also shows the occurrences of Lophelia associated with coral mound provinces that have been confirmed by seabed surveys (see also White et al., 2005).

\section{Survey methodologies}

A series of case studies are presented providing details from selected mound provinces. These case studies are based on a number of survey methodologies which are outlined briefly here.

Detailed bathymetric mapping of the Belgica mound province was performed using a $15.5 \mathrm{kHz}$ Hydrosweep DS2 multibeam echo sounder onboard RV Polarstern with a measurement accuracy of mostly better than $1 \%$ water depth (Beyer et al., 2003). A complete mosaic was generated with $10 \%$ overlap of survey swathes with a grid spacing of $50 \mathrm{~m}$. In addition to the depth measurements, echo amplitudes were recorded and used by Beyer et al. (this volume) for local seafloor classification. The bathymetry presented in the Hovland Mound province is of comparable resolution and was collected by the Geological Survey of Ireland using a Simrad EM120 instrument (see http://www.gsiseabed.ie/). Microbathymetry for the Logachev Mounds was obtained using a 200 kHz SIMRAD EM2000 mounted on the VICTOR 6000 ROV (see Klages et al., 2004).

Side-scan sonar coverage for the Hovland, Pelagia and Logachev mounds was collected using the $30 \mathrm{kHz}$ TOBI side-scan sonar system (Flewellen et al., 1993; De Haas et al., 2002). Additional side-scan sonar coverage in the Belgica, Pelagia and Darwin areas was also collected using a Geoacoustic dual frequency (100 and $410 \mathrm{kHz}$ ) high resolution side-scan sonar during RRS Discovery cruise 248 (Bett et al., 2001). Side-scan sonar coverage for the presented Norwegian case studies was surveyed using a Klein 595 dual frequency (100 and $500 \mathrm{kHz}$ ) and Ultra Electronics widescan dual frequency (100 and $310 \mathrm{kHz}$ ) high resolution side-scan sonars (Freiwald et al., 1999). Side-scan sonar data from all systems was processed using SOC's PRISM software (Le Bas \& Hühnerbach, 1999). An exception to this is the Oretech $30 \mathrm{kHz}$ low frequency side-scan sonar system that was also deployed in the Hovland Mound province and processed using standard methods (Akentieva \& Shashkin, 1998).

Ground-truthing of cold-water coral carbonate mounds was performed using the Jago submersible (Freiwald et al., 2002), ROV VICTOR6000 (Olu-Le Roy et al., 2002; Klages et al., 2004), towed video (Kenyon et al., 1998; De Bergé, 2000) and sediment samples (Swennen et al., 1998; De Mol et al., 1999; van Weering et al., 1999; de Haas et al., 2000, 2002, 2003, 2005; Freiwald et al., 2000, 2002b; de Stigter et al,. 2001; Van Rooij et al., 2001; De Mol, 2002;;Mienis et al., 2004). 


\section{Case studies from coral mound provinces}

Although it is not practical here to describe the variety of all European cold-water coral carbonate mounds, examples are presented below that illustrate the degree of variation between cold-water coral carbonate mounds that have been well studied. These case studies therefore provide a review of research on these cold-water coral carbonate mounds provinces which also form the main clusters of mounds along the European margin.

\section{Belgica Mounds, eastern Porcupine Seabight}

The Belgica mound province is situated on the eastern margin of the Porcupine Seabight between $51^{\circ} 10^{\prime} \mathrm{N}$ and $51^{\circ} 40^{\prime} \mathrm{N}$ (Fig. 2) and is aligned roughly north-south. In this area, based on multibeam echosounder and subbottom profiling systems (Beyer et al., 2003), 62 mound structures have been recorded (Fig. 3) of which 35 are outcropping mounds and 27 are buried. De Mol et al. (2002) found further buried mounds between $51^{\circ} 10^{\prime} \mathrm{N}$ and $51^{\circ} 20^{\prime} \mathrm{N}$ on seismic profiles making the total mound distribution extending 55km along the Porcupine Seabight margin.

The mounds occur in a depth range in between 700 and $1000 \mathrm{~m}$ and are bordered to the west (downslope limit) by a wide, north-south oriented channel (Fig. 3). The Belgica Mound province, and in particular its northern part, is pervaded by shallow south-west trending downslope channels which feed into the north-south channel (Van Rooij et al., 2003; Huvenne et al., 2005). These channels appear to be mostly relic at present. Mound distribution shows an alignment parallel to the continental margin with most structures forming single mound occurrences although they are often connected by sediment drift bodies and therefore appear as apparent clusters. As well as single mounds, some mounds coalesce at their bases (Henriet et al., 2003; De Mol et al., this volume).

Mound shape (see Fig. 4) varies from conical forms to elongated, ellipsoidal ridge-forms. Ridge-form orientation is at a slight angle with respect to the mound alignment and shows mainly a NNE - SSW orientation. Many mounds on the slope have an exposed steep western flank that is at about $20^{\circ}$ compared to the average slope of the margin at $c .5^{\circ}$. The eastern, upslope-side of the mounds is often buried by sediments which leads to a terracelike margin morphology. Depressions, up to $50 \mathrm{~m}$ deep, often occur on the steep downslope side of some mounds and are probably a result of strong bottom currents around some mounds (Van Rooij et al., 2003).

High resolution side-scan sonar imagery in inter-mound areas reveals numerous features indicative of high benthic current strengths including barchan dunes, seabed striations, comet marks, gravel ridges and sediment waves (Wheeler et al., 2005c). The sediment waves have large wavelengths of $20 \mathrm{~m}-25 \mathrm{~m}$ (De Mol et al., 2002) and reaching up to $100 \mathrm{~m}$ (Beyer et al., 2003).

The surface morphology of the mounds is also dominated by waveforms although video footage reveals that these, especially near mound summits, are coral banks mimicking off-mound sediment wave morphologies (Fig. 5). At the base of some mounds, a transition from non-coral colonised sediment waves to coral banks exists.

Also, in the vicinity of large cold-water coral carbonate mounds, small mounds (Moira Mounds) exist (Fig. 6) and could represent an early stage of the mound development (Foubert et al., 2005; Wheeler et al., 2005c).

Geological studies highlighting changing palaeoenvironmental conditions and mound growth histories show strongly punctuated sedimentation histories (Van Rooij et al., this volume).

\section{Hovland Mounds, northern Porcupine Seabight}

The Hovland Mound province is located in the north of the Porcupine Seabight, between $52^{\circ} 06^{\prime} / 52^{\circ} 22^{\prime} \mathrm{N}$ and $12^{\circ} 52^{\prime} / 12^{\circ} 05^{\prime} \mathrm{W}$ (Fig. 2). In this area, the bathymetric contours curve around the head of the Seabight and water depths range from 500 to $1000 \mathrm{~m}$. Slopes dip generally south- to south-westwards, with an angle of approximately $0.5^{\circ}$, which is reduced to $0.2^{\circ}$ just north(west) of the Hovland mounds (Magellan province). Further upslope to the north, Slyne Ridge connects the Porcupine Bank with the main Irish shelf.

The seafloor in the Hovland Mounds area is cut by 6 depressions or blind channels, generally running northsouth (except for one which bends towards the north-west: Fig. 7). They are between 10 and $17 \mathrm{~km}$ long and 70 to $150 \mathrm{~m}$ deep compared to the surrounding seafloor. Hovland et al. (1994) attributed them to bottom current erosion or to the escape of pore water or gases through the seafloor although De Mol (2002), based on detailed 
seismic study of the Hovland Mounds, suggested they were caused by current scouring by a northerly directed current.

Most of the Hovland Mounds (especially the larger ones), are associated with these channels: they are located along their flanks or at their heads. Increased current speeds and turbulence, caused by the presence of the mounds, may well have helped in the scouring and deepening of the depressions. The most western channel may even have been formed through the merging of several moats (scouring depressions created around the mounds).

The general seabed in the Hovland Mound province is of a uniform backscatter as imaged on the TOBI side-scan sonar mosaic (Huvenne et al., 2005). There is no evidence for bedforms such as ripples or sandwaves, and the backscatter intensity on the side-scan records is very homogeneous, although it seems to increase a little towards the north (Fig. 7a). Core descriptions of the area (Kenyon et al., 1998) identify these sediments as 'bioturbated foraminiferal marls or silts' with Dorschel et al. (2005: this volume), Rüggeberg, et al (2005) .and Rüggeberg, et al. (this volume) showing significant hiatuses in mound sequences. The overall environment of the Hovland Mounds at present is low energy with evidence of former higher energy conditions in the form of scoured moats and depressions. Image texture analysis of details of the OreTech side-scan sonar data indicated fundamental differences between the acoustic response of the mound flanks, the moats and background sediments (Huvenne et al., 2002).

Eleven large and 15 smaller surface mounds could be recognised on the TOBI side-scan sonar mosaic of the Hovland Mound province (Huvenne et al., 2005). Hovland et al. (1994) counted 31 surface mounds, but this included some structures which are now classified in the Magellan Mound province (Huvenne et al., this volume). De Mol (2002) found only 14 surface mounds on seismic data, but he may have counted close-by mounds as one structure if their sub-seafloor expression on the seismic records indicated a common base.

Most of the Hovland Mounds are grouped in 2 clusters: one towards the centre of the northern Seabight (Fig. 7) and one a little more on the northeastern flank. As stated above, most of the mounds are placed close to one of the depressions, which in the central group cause a strikingly rectangular cluster shape of c. 23 x 16km.

Several mounds have an elongated shape, with lengths varying from 1700 to 3200 or even $5000 \mathrm{~m}$, and widths of 450 to $1200 \mathrm{~m}$. Most of them are sharp ridges with several summits, others consist of multiple mound structures and some small mounds are lined up, as if they represent half-buried mound ridges. Some of the ridges are forked, with spurs extending in different directions. The overall directions of the ridges or lined-up mounds vary greatly (Fig. 7b). There are 4 mounds with a general east-west elongation, although 3 of them have a rather sinusoidal shape and one has several spurs directed to the north. Two mounds are elongated WNW-ESE, and one set of small mounds is lined up in a north-south direction. The largest mound in the central cluster (often referred to as the 'Propeller Mound': De Mol, 2002; Dorschel et al., 2005; Dorschel et al., this volume; Rüggeberg, et al., 2005; Rüggeberg, et al., this volume) consists of a north-south trending ridge, forking towards the north into ENE and WNW-ward pointing branches. The western branch then connects to another long ENE directed ridge. The ridges are generally not parallel to the depressions but are located at the heads of the blind channels.

\section{Pelagia Mounds, northwest Porcupine Bank}

Numerous steep-sided, giant cold-water coral carbonate mounds have been identified on the northwest Porcupine Bank (Kenyon et al., 1998; Akhmetzhanov et al., 2003; Kenyon et al., 2003; van Weering et al., 2003; Wheeler et al., 2005a) and are collectively known as the Pelagia Mounds (Fig. 2). These mounds exist between 500 and $1200 \mathrm{~m}$ water depth in an area on the Bank subjected to fast northerly flowing waters. The mounds occur downslope of a significant zone of iceberg ploughmarks and upslope of submarine canyons and slope failures (Fig. 8) (de Haas et al., 2002). A further cluster of giant carbonate mounds exists further south around the head of a major canyon system (Porcupine Bank Canyon Mounds) with smaller mounds also identified even further to the south (Grehan et al., 2006). Video observations of the seafloor (Olu-Le Roy et al., 2002; Wheeler et al., 2005a) and sediment samples (Kenyon et al., 2003; Klages et al., 2004) reveal a seabed typified by a thin cover of mobile rippled sands and areas of exhumed dropstones and hardgrounds (some of which have become colonised by corals).

Within the Pelagia Mound province, a number of scarp-features are identified on seismic lines and TOBI sidescan sonar data that have a slight topographic rise upslope and a steep scarp-face downslope. Cold-water coral carbonate mounds are often, although not exclusively, found on top of these scarps (Fig. 9). The scarps run subparallel to the isobaths and their shape and downslope acoustic facies suggests that these are not associated with 
slope failures but may represent either the edges of erosional scours where low-angle bedding is exposed, or fault scarps associated with underlying boundary faults. In support of the former, comparable (although much smaller scale) erosional exposures of consolidated sediment exposures have been identified in this area from ROV footage (Olu-Le Roy et al., 2002; Wheeler et al., 2005a) and also previously imaged on high-resolution side-scan sonar records (Akhmetzhanov et al., 2003). These exposed consolidated sediments have become coral colonised (Fig. 10). In support of the latter, industrial seismic data suggests a correlation between Rockall Trough boundary faults and the scarps (Croker et al., 2002) that would support the gas-seep hypothesis for mound formation (Hovland et al., 1994), although disputed by Wheeler et al. (2005a).

The cold-water coral carbonate mounds in the Pelagia Mound province are giant mounds being predominantly 100 to $>300 \mathrm{~m}$ across and ranging in height up to $c .250 \mathrm{~m}$. At present, coral colonisation is mainly restricted to their summits. They occur both as isolated features and in association with the scarps. Mound shape ranges from ovoid, to ridge-shaped running sub-parallel to the isobaths, to complex forms. Some of the mounds, especially those occurring as groups, are also surrounded by zones of high backscatter seabed suggesting either coral rubble/live coral spreading off of the mounds or a coarse gravely substrate in the mound vicinity due to high benthic current speeds (Fig. 11). A few mounds also show low backscatter moats.

The giant mound cluster is aligned perpendicular to the slope although in other instances, there is a clear tendency for along-slope mound alignment. This alignment usually occurs either on the slope parallel scarp features (Fig. 11) or, in one instance, along the crest of a slope parallel topographic spur at the head of a canyon system (Fig. 8).

\section{Logachev Mounds, eastern Rockall Bank}

The Logachev Mounds exist on the southern eastern Rockall Bank between 500 and 1200m water depth (Fig. 2) and form a complex arrangement of coalescing mound clusters that are aligned both up- and downslope. Mienis et al. (in press) discusses these mounds in detail. A sediment wave field exists upslope of the mounds with wavelengths of up to $500 \mathrm{~m}$ long and individual waves being traced for several kilometres. Downslope of the Logachev Mounds is a $5 \mathrm{~km}$ wide area of very low backscatter revealing slope parallel flow features and slide escarpments.

The Logachev Mounds possess diameters in the order of hundreds of metres to a few kilometres. Mound clusters are predominantly aligned north-south (downslope), east-west (along-slope) aligned mound clusters are also present (Fig. 12). Seismic evidence suggests that the north-south mound clusters were initiated earlier than the east-west mound clusters (van Weering et al., 2003).

In between the mound clusters, narrow and elongated areas of low backscatter are present running downslope although occasionally these structures run along slope. The structures are interpreted as valleys in between the mounds acting as channels through which (tidal) currents are funnelled. Boxcores from these areas usually retrieve only pebbles and boulders (e.g. De Haas et al., 2000). Video observations (Olu-Le Roy et al., 2002) from these areas show a largely sediment starved environment with evidence of scour.

High resolution multibeam and video data (Olu-Le Roy et al., 2002) reveals a terraced morphology to the mounds with the fronts of the terraces colonised by live coral and the backs of terrace characterised by exposed dead coral skeletons. Interstitial sediment between the coral frameworks is minimal (Fig. 13).

\section{Norwegian mounds}

The northernmost occurrences of Lophelia exist in Scandinavian waters from the Swedish Kosterfjord area (Jonsson et al., 2004: Wisshak et al., 2005) to the southwestern Barents Sea at $71^{\circ}$ northern latitude (Freiwald et al., 1997: Lindberg \& Mienert, 2005). Through intense seabed mapping efforts and collated reports by fishermen, more than 1000 geographically referenced Lophelia locations are now known (Fosså et al., 2002; Fosså et al., 2005). Corals are most abundant on the continental shelf specifically along the upper slope of the continental margin and along many flanks of the deep mid-shelf troughs in the bathymetric range of 200 to 400 $\mathrm{m}$ water depth (Fig. 2). Fjord systems which lack a shallow sill near the entrance, thus permitting the episodic intrusion of oceanic water through estuarine circulation patterns, provide another suitable environmental setting for Lophelia reefs and patches as shallow as 38m water depth have been found (Dons, 1944; Freiwald et al., 1997; Fosså et al., 2000). 
During the Neogene glaciations the waning and waxing glaciers repeatedly reached the shelf and occasionally also the shelf-break in certain areas of the Norwegian Shelf (Vorren et al., 1983). These glaciogenic processes caused erosion but also deposition of a sequence of moraines onto the shelf. During the final postglacial collapse of the Fennoscandian ice shield, drifting icebergs frequently grounded thereby producing ploughmarks and flutes (Lien, 1983), or released scattered ice-rafted debris in the form of dropstones on the seabed. These marine Pleistocene glaciogenic processes provided a broad array of suitable hard substrata for the arriving Planula larvae of Lophelia during the climatic amelioration. Typical coral-rich grounds are elevated moraines and boulder levees of ploughmarks (Freiwald et al., 1999). Oldest radiocarbon dates obtained from Lophelia skeletons from various sites off mid and southern Norway cluster around 8,700 to 8,600 years BP for the Early Holocene coral colonisation (Mikkelsen et al., 1982, Rokoengen \& Østmo, 1985, Hovland et al., 1998). Since then the framework-constructing potential of Lophelia has resulted in the formation of impressively large buildups, commonly called coral banks, bioherms, or reefs (Teichert, 1958; Mortensen et al., 1995; Mortensen et al., 2001; Freiwald, 2002).

Despite the large number of Lophelia occurrences known in Scandiavian waters, only a few sites have been analysed in great detail. One of the best known study sites is the Sula Reef Complex (SRC) at $64^{\circ}$ northern latitude (Hovland et al., 1998, Mortensen et al., 1995, 2001; Freiwald et al., 2002). The SRC stretches over $14 \mathrm{~km}$ in lateral extension along a spur - the Sula Ridge. The ridge forms a northeastward continuation of the Frøyabank and is underlain by a tilted Paleocene sandstone unit. A thin cover of Late Pleistocene moraine deposits was left behind after the last glacier advance onto the shelf. During the deglaciation grounding icebergs carved out both the morainic deposits and parts of the Paleocene sandstone unit. Especially on the shallowest parts of the ridge, the incised furrows of the iceberg ploughmarks are flanked by boulder-rich levees which exert an important control of the present day general outline of the SRC (Freiwald et al., 1999). Individual Lophelia build-ups can be grouped into morphological categories (Mortensen et al., 2001; Freiwald et al., 2002). Buildups with a height less than $10 \mathrm{~m}$ are often single-peaked and possess a circular outline measuring 20 to $70 \mathrm{~m}$ across (Fig. 14a). The larger build-ups are elongated and multi-peaked with heights between $>10$ to $25 \mathrm{~m}$ indicating that these may originate from coalescing neighbouring reefs (Fig. 14b). The lateral extension is variable, ranging from 200 to $1000 \mathrm{~m}$ with a width of 40 to $120 \mathrm{~m}$ near the base. Both Lophelia reef shape groups show the same basic arrangement of sedimentary facies and biological habitats. Two major sedimentary facies characterise the off-reef environments: the bioturbated silty sand facies and the sponge-rich boulder ground facies. The reef-associated facies generally provide a consistent lateral sequence from the distal and deeper lying base to the proximal reef top (Fig. 14c): (1) Pebbly sand facies, (2) Coral rubble facies, (3) Sediment-clogged coral framework facies, (4) Exposed dead coral framework facies, and (5) Living coral framework facies. Regardless of direction or the degree of current exposition, no evident variation of the facies sequence was documented during the ground-truthing operation (Freiwald et al., 2002).

High-frequency $(>100 \mathrm{kHz})$ side-scan sonar records yield characteristic backscatter features that provide valuable information for the recognition and identification of Lophelia occurrences on the seabed specifically for Scandinavian waters. The geographical restriction is related to the distinct colony shape of Lophelia that differs strongly from Lophelia colonies found elsewhere along the northwestern European continental margin. A living coral framework viewed with a side-scan sonar resembles a giant cauliflower (Figs. 14a \& b; Freiwald et al., 1999). Ground-truthing with a manned submersible proved that this feature originates from individual hemispheroidal coral colonies measuring up to $1.5 \mathrm{~m}$ in thickness and up to $2 \mathrm{~m}$ in diameter. Ideally, this type of a Lophelia colony has a circular outline. Occasionally larger hemispheroidal coral colonies were observed. These huge colonies start to collapse from the central inner core predominantly due to the bioerosional effect of boring sponges. This characteristic feature ("Wilson-Ring") is detectable on the sonographs and was predicted to occur during the ontogenetic evolution from a single polyp to a mature colony stage by Wilson (1979b).

Further studies by Mortensen et al. (2001) and Fosså et al, (2005) on Lophelia distributional patterns in a wider geographical context on the Norwegian Shelf yield evidence that coral reefs preferably occur close to breaks and escarpments but much less on the level bottom. In fjords, moraine sills with their turbulent hydrodynamic regime seem to provide nourishing conditions for coral growth as has been demonstrated for the Stjernsund Reef at $70^{\circ}$ northern latitude (Fig. 15). Lophelia reefs occur in areas with high densities of pockmarks but also in areas where no pockmarks were found. Hydrocarbon seepage as a nutritional agent may stimulate the entire food web as suggested by Hovland et al. (1997) (see discussion in Freiwald et al., 2002), as long as hydrocarbon emissions are not too strong to kill the oxygen-demanding communities. 


\section{Discussion}

\section{Cold-water coral carbonate mound development}

The process of mound development has been investigated by several authors and the principle aspects of this process are outlined below. The framework building capacity of Lophelia enables it to grow upwards into the water column. In doing so, Lophelia can feed in faster flowing waters, thus increasing food flux, and isolating itself from detrimental bedload and heavy particle suspended load transport associated with the benthic boundary layer, whilst still benefiting from fine organic suspended sediment flux. However, due to the effects of bioeroders and hydrodynamics, colonies eventually keel over and provide an elevated platform for new growth. Vertical mound growth is also assisted by sedimentation around colonies that provides structural support to the colonies provided that coral colony growth rates are in excess of on-mound sedimentation rates. Once mounds reach a certain height they become isolated from bedload transport and mound growth style changes. For Lophelia a more suitable habitat is therefore created with an increase in organic particle supply due to faster flowing waters and higher organic:lithic suspended sedimentation ratios.

Despite the commonality of this process, the above case studies highlight the degree of variability that exists in the resultant morphology of cold-water coral carbonate mounds that vary from small scale to giant mounds, conical mounds to ridge-shaped features, and framework dominated to sediment dominated. A central tenant of this discussion is that this morphological variation is an expression of the influence of differing environmental controls (e.g. the influence of the following important environmental parameters: current dynamics, temperature, salinity, $\mathrm{pH}$, organic particulate supply, vertical and bedload sediment supply) on mound growth. The morphology of mounds can therefore provide us with clues to the environment conditions once certain relationships have been defined. Although it is perhaps over-optimistic to assume that simple seabed mapping of cold-water coral carbonate mounds can unlock the complexities of environmental dynamics in mound areas (Wheeler et al., subm.), it is useful to make some basic observations and draw relationships that may help to explain the variety in mound morphology and explore the underlying environmental controls.

\section{Environmental controls on cold-water coral carbonate mound distribution}

As well as controlling morphology, environmental conditions also dictate, perhaps in a more fundamental way, mound distribution and occurrence. Figures 1 \& 2 show that Lophelia and associated cold-water coral carbonate mounds are found predominantly along continental margins and seamounts at intermediate water depths. Unlike tropical scleractinians, Lophelia does not possess a symbiotic relationship with algae and is therefore not restricted to the photic zone. However, occasional isolated finds do occur in shelf seas and, in more northern waters (e.g. offshore Norway) exclusively on the shelf and even in fjords (Dons, 1944; Freiwald et al., 1997; Fosså et al., 2000). This distribution is an expression of the ecological tolerance of Lophelia particularly with respect to temperature. It is at these water depths that temperatures fall within the range of $4-13^{\circ} \mathrm{C}$. Lophelia can tolerate a range of salinity (Rodgers, 1999) (making it adaptable in fjordic settings) but as a suspension feeder, shows a preference for areas with high current speeds and high concentrations of suspended organic particulate material. It also requires a hard substrate to grow on although this may include dead coral skeletons allowing, in theory, considerable communities to grow from one isolated dropstone.

However, despite its wide distributions along the European margin, Lophelia is not evident in all areas where these ecological constraints are met and it only forms cold-water coral carbonate mounds in a few of these. A study of the distribution of cold-water coral carbonate mounds (Fig. 2) suggests that specific conditions are needed for their formation.

One obvious control is the need for suitable substrates for initial coral attachment that can include dropstones or, as in the Pelagia Mound area, the exposure of consolidated sediment. The absence of Lophelia in some areas of the margin may represent a lack of suitable substrates although many areas with suitable substrates at appropriate water depths exist where Lophelia is not present (e.g. the eastern Rockall Trough margin: see Wheeler \& TTR9 Shipboard Scientific Party, 2000). Unsuitable muddy substrates exist at present in the Hovland Mound area with coral growth restricted to the summits of cold-water coral carbonate mounds where attachment is on old coral frameworks and there is no new off-mound coral growth. The muddy seabed conditions may reflect sluggish water dynamics at present and may therefore also explain the low abundance and restricted nature of living coral 
as present. Moats around mounds in this area suggest that vigorous currents were typical of the palaeoenvironment in this area when these mounds may have been more productive.

Two main theories have been presented that may explain why cold-water coral carbonate mounds are found in discrete provinces and are absent elsewhere. Firstly, cold-water coral carbonate mounds are linked to hydrocarbon seepage, and/or secondly specific hydrodynamic conditions exists that are optimal for Lophelia in specific areas. Hovland (1990) first suggested that cold-water coral carbonate mounds restricted locations are related to cold seeps where enhanced bacterial activity forms the base of a food chain supporting a diverse and abundant biological community (including Lophelia) and also provides conditions suitable for abundant carbonate production. Hovland et al. (1994) then went on to associate the Hovland Mounds with underlying faults acting as a conduit for hydrocarbon seepage. However, isotopic studies of Lophelia to date (e.g. De Mol et al., 1998; Kiriakoulakis et al., 2001) suggest that carbon incorporated into their skeleton is contemporary and not derived from older thermogenic sources. This suggests that mound growth is not dependent on ongoing hydrocarbon seepage. However, a lack of isotopic samples from corals from the base of cold-water coral carbonate mounds allows for the possibility that cold-water coral carbonate mounds may have been initiated by gas seepage, and once they have grown significantly, can function independently of further seepage and may, in fact cap the initial seeps (Henriet et al., 2001). Preliminary results from recent drilling of the base of the Challenger Mound (Belgica Mound Province) found no evidence for thermogenic gas (Expedition Scientists, 2005). Some credibility to this theory, however, is given by coincidence of mound occurrences overlying hydrocarbon reservoirs, by hydrocarbon seepage modeling (Naeth et al., this volume) that predicts seafloor hydrocarbon seepage pathways directed to the Hovland and Belgica Mounds and by the occurrence of Lophelia in sheltered environments within pockmarks in Norwegian waters (Hovland, 2005). This may also explain why these mounds reach such large proportions compared with other smaller mounds.

The second theory explaining why cold-water coral carbonate mounds are found in discrete provinces emphasises the specifics of hydrodynamics in areas that are particularly favourable to Lophelia growth. Lophelia occur in areas subjected to strong currents and prefer sites that are elevated with more prolific growth occurring on exposed flanks and summits. Additionally, Lophelia occurrences coincide with the Oxygen Minimum Zone in the north Atlantic (Freiwald, 1998) related to intermediate nepheloid layers containing enhanced concentrations of organic particulate material and associated with water column stratification (Kenyon et al., 2003). Current dynamics on continental margins where Lophelia occurs include geostrophic currents often associated with internal waves that may steepen and break along the continental slope, and internal tides. It may be that the interplay between internal waves, tidal currents and the slope gradient induce conditions of near-resonance where current dynamics is at its optimum for suspension feeders (White et al., 2005). The influence of current dynamics also has a major influence on gross mound morphology (see below). On a global view, Lophelia occurrences cluster in areas of high seasonal primary production, thus indicating a strong bentho-pelagic coupling as the major driver for carbon transfer from productive surface waters to the coral ecosystem (Guinotte et al., 2006). This is also supported by biomarker analyses of coral soft tissue indicating plankton as the major food source (Kiriakoulakis et al. 2005, this volume).

\section{Cold-water coral carbonate mound size relationships}

The size of giant cold-water coral carbonate mounds may not solely be an expression of optimum conditions for growth. Their size may be more a function of longevity where recurrent favourable conditions have occurred through the Pleistocene. This situation may be aided by the fact that once formed, the mounds provide there own elevated environment more suitable for renewed coral colonisation. In this context, many of the smaller mound forms observed, e.g. Moira Mounds, Darwin Mounds and Norwegian mounds are probably younger (Early Holocene). For Norwegian mounds this is certainly true as they grow on Devensian glacial deposits.

O’Reilly et al. (2003) analyses mound size relationships for the Pelagia Mounds and, erroneously equating a published cold-water coral polyp growth rate to mound growth rates, derive an age model for mound initiation. An underestimation is achieved which is further compounded as we now know mound sequences contain many hiatuses/erosion in mound sequences (e.g. see Dorschel et al., 2005).

A similar exercise in mound size comparisons is presented here for the Belgica Mound province based on multibeam echosounder data (although not related to a growth model). The data of 35 surface mounds and 27 buried mounds were used to calculate statistics for this province (Fig. 3). Figure 16 illustrates the depth distribution of the mound bases and summits for the Belgica Mound province. The mound bases are defined as the deepest bathymetric depth of the mounds where the surface slope changes from mound flank towards general 
slope. The mounds are supposed to be symmetrical and shallower depths are due to partial burial at one side (mostly the eastern upslope side). The mound summits are found at the center of the mound structures indicating the shallowest depth. Summits occur in two main water depths: $850 \mathrm{~m}$ and $700 \mathrm{~m}$. The mound bases show a similar depth distribution and occur mainly at $950 \mathrm{~m}$ and $800 \mathrm{~m}$ water depth where they possibly formed on a Late Pliocene erosion surface (Van Rooij et al., 2003; Expedition Scientists, 2005). Although the mounds north of $51^{\circ} 30^{\prime} \mathrm{N}$ are more weakly aligned, they also support this depth dependent distribution. The depths of mound summits (Fig. 16a) and mound bases (Fig. 16b) correlate with an r-value of 0.93 showing a strong uniformity of mound height and position with respect to initiation and elevation in the water column. In addition, the depth distribution of the buried mound summits corresponds to the distribution of the exposed mound summits at $700 \mathrm{~m}$ water depth. Depths of the mound bases of buried mounds are not available from bathymetry.

Exposed heights of the mounds vary between $10 \mathrm{~m}$ and $70 \mathrm{~m}$ (mean: $40 \mathrm{~m}$ ) on their upslope side and $40 \mathrm{~m}$ and $160 \mathrm{~m}$ (mean: 90m) on downslope side (Fig. 17). The mean height of the mounds is c.100m based on the depth histograms (Fig. 16a \& b). The horizontal extent of the mounds is presented in Figure 18. The north-south width has a broader range than the east-west extension: varying between $400 \mathrm{~m}$ and $2000 \mathrm{~m}$ (mean: $860 \mathrm{~m}$ ) and 300m and $1000 \mathrm{~m}$ (mean: 570m) respectively. However, mound size slightly decreases in the northern part of the mound province where the slope gradient is gentler (in particular north of $51^{\circ} 30^{\prime} \mathrm{N}$ ).

This mound morphometric data presented here for the Belgica Mound shows that the distribution of the mound heights (downslope and upslope sides) shows a left-shifted distribution which means that smaller heights are more common compared to large heights (Fig. 17). However, this feature is more pronounced for the upslope side as a result of sedimentation. The histograms shown in Figs. 16 to 18 are useful for comparison with mound characteristics of other provinces with a similar left-shifted distribution (in this case lognormal) was reported for the largely buried Magellan mounds in the northern Porcupine Seabight (Huvenne, 2003; Huvenne et al., this volume)..

\section{"Inherited" and "developed" mound morphological types}

As well as mound location and scale, environmental factors strongly dictate mound morphology. Two types of gross mound morphological forms can be defined: "inherited" forms and "developed" forms as discussed below. Inherited forms have a strong substrate control and owe their gross morphology to the morphology of the features that have been colonised. Developed forms have grown independently of the topography at their original colonisation site and assume forms more closely in equilibrium with prevailing hydrodynamic conditions.

The tendency of Lophelia to grow in elevated exposed settings means that preferential sites of colonisation are often on topographic features such as morainic ridges. The Sula Ridge is a case in point where the gross morphology of the coral mound is ridge-shaped, as the name implies, growing as it does on a continuation of the morainic Frøyabank (Freiwald et al., 1999). In this example, we also see a further substrate control with the boulder levees of iceberg ploughmarks offering elevated, hard substrate sites for colonisation (Fig. 14). Similarly, the gross morphology of mounds on scarps in the Pelagia Mound province reflects the geometry of the scarps with mounds extending along the crests (Fig. 9). In both instances it is the pre-existing morphology of the settlement sites that ultimately dictate gross mound morphology

Masson et al. (2003) suggested a fluid escape mechanism for the Darwin Mounds in the northern Rockall Trough implying that these are coral-colonised pockmarks based on a dimensional coincidence between the two features and observations of transitional partially colonised pockmarks. Masson et al. (2003) argue that the pockmarks were formed by the dewatering of underlying sediments, which brings suitable coarse-grained substrates to the surface in the areas where the pockmarks are colonized. This process would have no relationship to any type of hydrocarbon seepage. In this context, mound occurrence is directly controlled by the localized nature of suitable substrates with mound morphology inherited from the morphology of the pockmarks through substrate control. To the east of the Darwin Mounds, coral colonisation occurs on a seabed with a dense scattering of dropstones forming a dispersed coral cover with no tendency for mound formation (Wheeler et al., subm.). Wheeler et al. (subm.) goes on to demonstrate a transition from inherited to more developed morphologies for the Darwin Mounds related to increasing bedload transport.

Radiocarbon dates from Norwegian cold-water coral carbonate mounds confirms these as Early Holocene (Mikkelsen et al., 1982, Rokoengen \& Østmo, 1985, Hovland et al., 1998), whereas the age of the Darwin Mounds and Pelagia scarp mounds is speculative. However, all of these mounds are relatively small implying that the mounds are probably no older than Holocene in age and were initiated when hydrodynamic conditions 
and sediment supply regime altered favourably for Lophelia. We can therefore postulate that mound morphology of relatively young mound tends to be "inherited" simply because the mounds have not had time to develop a morphology independent of their sites of colonisation. In contrast, the giant mounds tend to have a "developed" morphology that may be an expression of their longevity. Dates for the initiation of these mounds are inferred as Pliocene (Hovland Mounds - De Mol et al., 2002), Miocene to Late Pliocene (Belgica Mounds - De Mol et al., 2002; Van Rooij et al., 2003) and early Tertiary to early Pliocene (Logachev Mounds - van Weering et al., 2003).

The gross morphology of the Belgica Mounds is clearly current aligned. The strong correlation of mound height may also suggests that the Belgica Mounds have developed an optimal elevation with all summits now stabilised within the same water mass.

In the Hovland Mound province elongated mounds and several simple elliptic or conical mounds are observed. Most of those, however, seem to occur in the eastern cluster. The elongation of the mounds, together with the occurrence of forked ridges and spurs, suggests the influence of currents on the morphology of the Hovland Mounds. As most of the spurs and forks are directed more or less north-south, this could indeed indicate a northsouth directed current. A similar effect was described for the Magellan province (Huvenne et al., this volume).

The Hovland Mounds also show a preferred positioning around the rim of channels. This suggests that gross mound morphology has developed in response to the influence of the channels that may provide enhanced food supply from waters flushing out of them. De Mol et al. (2002), when providing evidence against a hydrocarbon seepage model for the Hovland Mounds, noted that mound alignment was not coincident with underlying faults.

Internal tides are also important along these marginal settings with developed mound morphologies in both the Pelagia Mounds and Logachev Mounds (Fig. 2) dominated by the influence of up- and down-slope tidal current activity. In the Logachev Mounds, mound clusters are aligned both along-slope and perpendicular to the slope. Seismic evidence (van Weering et al., 2003) suggests that these differently aligned clusters are of different ages. This suggests that initial mounds were aligned along-slope, due to the dominant influence of geostrophic currents, and subsequently aligned perpendicular to the slope due to a rise in the dominance of tidal currents.

\section{Mound surface-morphology}

The survey data summarised here also reveal information about the surface morphology of mounds. On the Sula Ridge (Freiwald et al., 1999) the surface morphology is "cauliflower shaped" (Fig. 14) revealing a surface morphology reflecting the biological growth forms of mature Lophelia colonies. The overall surface morphology is created by colonies distancing themselves from neighbours as closer colonies are "overshadowed" and stunned due to reduced food supply. A similar form is presented for the Moira Mounds (Fig. 6) and also for the Darwin Mounds (Wheeler et al., 2000; Masson et al., 2003; Wheeler et al., subm.).

The surface morphology of the Belgica Mounds and Logachev Mounds (Olu-Le Roy et al., 2002; Wheeler et al., 2005c) is dominated by ridges covered with coral growing into coral banks (Fig. 5b). These banks are nonmigratory waveforms although, in the case of the Belgica Mounds, sand transport onto the banks helps to provide support for coral colonies thereby facilitating further bank vertical growth. The original holdfasts of coral colonies are probably glacial dropstones presently buried below the coral banks and Holocene sediment drift deposits.

This surface morphology is again biological controlled with growth on top of the banks benefiting from enhanced food supply while growth of those in the trough regions become "overshadowed" and stunted. The development of banks, as opposed to isolated colonies, may purely be an expression of this process occurring on a steep slope.

\section{Conclusion}

Extensive seabed mapping in recent years has enabled detailed observations and comparison of mound gross and surface morphologies between various cold-water coral carbonate mounds along the European margin. The morphology of the mounds is an expression of the environmental controls and constraints under which these 
mounds grew. In some cases, gross mound morphology is "inherited" from the morphology of features that were colonized because they offered suitable substrates or topographically elevated settings favourable to Lophelia growth. In other cases, mounds have assumed their own gross "developed” morphology that tends to be aligned with dominant hydrodynamic conditions.

Details of mound surface morphology suggest that the growth of one coral colony "shadows" the surrounding seabed restricting the growth of immediate neighbours. On low relief mounds this results in an irregular surface morphology dominated by discrete coral colonies (the cauliflower morphology of Freiwald et al., 1999). On mounds with steep flanks, coral banks can be formed with similar morphologies to sediment waves. Surface morphologies are strongly dictated by biological growth forms although environmental factors, particularly sediment supply and erosion, may play a significant part.

\section{Acknowledgements}

The authors would like to acknowledge the following contributions. TOBI data collection was undertaken with financial support of the European Union (EASSS III programme, 'Improving Human Potential', contract HPRICT-1999-00047) and the Porcupine Studies Group (PSG) of the Irish Petroleum Infrastructure Programme Group 3. The PSG comprises: Agip Ireland BV, Chevron UK Ltd, Elf Petroleum Ireland BV, Enterprise Energy Ireland Ltd, Marathon International Hibernia Ltd, Phillips Petroleum Company United Kingdom Ltd, Statoil Exploration (Ireland) and the Department of Communications, Marine and Natural Resources of the Irish Government.. Other datasets were collected under the auspices of EU Fifth Framework Programme Projects; ACES “Atlantic Coral Ecosystem Study" (Contract number: EVK3-CT-1999-00008), ECOMOUND "Environmental Controls on Mound Formation along the European Margin" (Contract number: EVK3-CT-199900013) and GEOMOUND “The Mound Factory - Internal Controls” (Contract number: EVK3-CT-1999-00080). Contributions by on eof the authors (Veerle Huvenne) was funded through the 'Fonds voor Wetenschappelijk Onderzoek - Vlaanderen' and under a European Marie Curie post-doctoral fellowship and honorary post-doc fellowship with the FWO-Vlaanderen.

\section{References}

Akentieva, E. \& Shashkin, P., 1998. OKEAN and OREtech sidescan sonars and sonar processing. In: N. H. Kenyon, M. K. Ivanov, A. M. Akhmetzhanov (Eds) Cold water carbonate mounds and sediment transport on the Northeast Atlantic margin. IOC Technical Series 52, 11-12.

Akhmetzhanov, A. M., Kenyon, N. H., Ivanov, M. K., Wheeler, A. J., Shashkin, P. V. \& van Weering, T. C. E., 2003. Giant carbonate mounds and current-swept seafloors on the slopes of the southern Rockall Trough. In J. Mienert, P. Weaver (Eds) European Margin Sediment Dynamics: Side - Scan Sonar and Seismic Images. Springer-Verlag, p. 203-209.

Beyer, A., Schenke, H.W., Klenke, M. \& Niederjasper, N., 2003. High resolution bathymetry of the eastern slope of the Porcupine Seabight. Marine Geology, 198, 27-54.

Beyer, A., Bishwajit Chackraborty, B. \& Schenke H.W., this volume. Seafloor characterization of the mound and channel provinces of the Porcupine Seabight - an application of the multi-beam angular backscatter data. This volume

De Bergé, B. (2000). Epi- en endofauna geassocieerd met koudwaterkoralen in de NO Atlantische Oceaan. MSc thesis, Marine Biology Department. Gent, University of Gent, 133 pp.

De Mol, B., 2002. Development of coral banks in Porcupine Seabight (SW Ireland). A multidisciplinary approach. Faculty of Sciences, Department of Geology and Soil Science. Ghent, University of Ghent, 363.

De Mol, B., Friend, P., Akhmetzhanov, A., Ivanov, M., de Haas, H., Belenkaya, I. \& Stadnitskaya, A. (1999). Porcupine Seabight : short visit. In: Kenyon, N.H., Ivanov, M.K. and Akhmetzhanov, A.M. (Eds.). Geological processes on the Northeast Atlantic Margin, UNESCO, Paris, IOC Technical Series, 54, 34-47

De Mol, B., Kozachenko, M., Wheeler, A., Alvares, H. \& Henriet, J.P., this volume. Thérèse Mound: a case study of mound development in the Belgica Mound Province, Porcupine Seabight.

De Mol, B., Swennen, R. \& Henriet, J.P., 1998. Sedimentology and geochemical characteristics of a core taken from a “Hovland” Mound. In: B. De Mol (ed) Geosphere-biosphere Coupling: Carbonate Mud Mounds and Cold Water Reefs. Intergovernmental Oceanographic Commission Workshop Report No. 143, p. 26-27.

De Mol, B., Van Rensbergen, P., Pillen, S., Van Herreweghe, K., Van Rooij, D., McDonnell, A., Huvenne, V., Ivanov, M., Swennen \& R., Henriet, J.P. 2002. Large deep-water coral banks in the Porcupine Basin, southwest Ireland. Marine Geology 188, 193-231.

De Mol, B., Henriet, J.P. \& Canals, M. (2005). Development of coral banks in Porcupine Seabight: do they have Mediterranean ancestors? In: A. Freiwald \& J.M. Roberts (eds). Cold-water corals and Ecosystems, Springer-Verlag, 515-533. 
de Haas, H., Grehan, A., White, M., \& Shipboard Scientists, 2000. Cold water corals in the Porcupine Bight and along the Porcupine and Rockall Bank Margins. Cruise Report Cruise M2000 of R.V.Pelagia (64PE165). Unpublished Report, NIOZ, 26pp.

de Haas, H., Huvenne, V., Wheeler. A., Unnithan, V. \& shipboard scientific crew, 2002. M2002 Cruise report (R.V. Pelagia Cruise 64PE197): A TOBI Side Scan Sonar Survey of Cold Water Coral Carbonate Mounds in the Rockall Trough and Porcupine Sea Bight - Texel-Southampton-Galway, 21 June - 14 July 2002. Royal Netherlands of Sea Research, Texel, The Netherlands, 2002.

de Haas, H., Mienis, F., Shipboard Scientific Party, 2003. Report of cruise Moundforce 2003. The distribution, morphology and sedimentology of mud mounds in the Faeroe Shetland Channel and carbonate mounds at the SW Rockall Trough margin. Unpublished Report, NIOZ, 90 pp.

de Haas, H., Mienis, F., Shipboard Scientific Party, 2005. Cruise report R.V. pelagia M2005 (64PE237). Cold water corals and carbonate mound formation at the Pen Duick escarpment 9Gulf of Cadiz) and Rockall Bank. Report, NIOZ, 80 pp.

de Stigter, H., de Haas, H., Shipboard Scientific Crew, 2001. Report of cuise M2001 with R.V. Pelagia. Cold water corals along the SE and SW Rockall Trough margins. Unpublished Report, NIOZ, 90 pp.

Dons, C., 1944. Norges korallrev.- Det Kongl. Norsk. Vidensk. Selsk. Forh., 16: 37-82.

Dorschel, B., Hebbeln, D, Rüggeberg, A. \& Dullo, C. (this volume). Carbonate budget of a cold-water coral carbonate mound: Propeller Mound, Porcupine Seabight

Dorschel, B., Hebbeln, D, Rüggeberg, A. \& Dullo, C. \& Freiwald, A. (2005) Growth and erosion of a cold-water coral covered carbonate mound in the Northeast Atlantic during the Late Pleistocene and Holocene Earth and Planetary Science Letters, 233, 33-44.

Duineveld, G. C. A., Lavaleye, .M. S. S., Berghuis, E. M. (2004) Particel flux and food supply to a seamount cold-water coral community (Galicia Bank, NW Spain) Mar. Ecol. Prog. Ser. 277, 13-23.

Expedition Scientists, "Modern carbonate mounds: Porcupine drilling” (Tech. Rep. IODP Prel. Rept. 307, DOI: 10.2204/iodp.pr.307.2005, 2005).

Flewellen, C.G., Millard, N.W. \& Rouse, I.P. (1993). TOBI, a vehicle for deep ocean survey. Electron. Commun. Eng. J., 5, 85-93.

Fosså, J.H., Mortensen, P.B. \& Furevik, D.M. (2000): Lophelia-korallrev langs norskekysten forekomst og tilstand.- Fisken og Havet, 2: 1-94.

Fosså, J.H., Mortensen, P.B. \& Furevik, D.M. (2002): The deep-water coral Lophelia pertusa in Norwegian waters: distribution and fishery impacts. Hydrobiologia, 471: 1-12.

Fosså, J.H. Lindberg, B., Christensen, O., Lundälv, T., Ingvald, S., Mortensen, P.B., Alvsvåg, J. (2005). Mapping of Lophelia reefs in Norway: experiences and survey methods. In: A. Freiwald \& J.M. Roberts (eds). Cold-water corals and Ecosystems, Springer-Verlag, 359-391.

Foubert, A., Beck, T., Wheeler, A.J., Opderbecke, J., Grehan, A., Klages, M., Thiede, J., Henriet, J.P. \& the Polarstern ARKXIX/3a shipboard party (2005) New view of the Belgica Mounds, Porcupine Seabight, NE Atlantic: Preliminary Results from the Polarstern ARK-XIX/3a ROV cruise. In: A. Freiwald \& J.M. Roberts (eds). Cold-water corals and Ecosystems, Springer-Verlag, 403-415.

Frederiksen, R., Jensen, A. \& Weesterberg, H. (1992). The distribution of the scleractinian coral Lophelia pertusa around the Faroes Islands and the relation to internal tidal mixing. Sarsia, 77, 157-171.

Freiwald, A., 1998. Geobiology of Lophelia pertusa (Scleractinia) reefs in the North Atlantic. Unpublished Thesis, University of Bremen, Bremen

Freiwald, A. (2002): Reef-forming cold-water corals. Ocean Margin Systems. G. Wefer, Billett, D., Hebbeln, D., Jørgensen, B.B., Schlüter, M. and van Weering, T.C.E. Heidelberg, Springer: 365-385.

Freiwald, A., Fosså, J.H., Grehan, A. Koslow, T. \& Roberts, J.M. (2004): Cold-water Coral Reefs.- UNEP-WCMC, Cambridge, UK, 84 pp

Freiwald, A., Dullo, W.C. \& Shipboard Party (2000). RV Poseidon cruise 265, Thorshavn - Galway - Kiel, 50 pp.

Freiwald, A., Henrich, R \& Pätzold, J. (1997). Anatomy of a deep-water coral reef mound from Stjernsund, west Finnmark, north Norway. In: N.P. James \& A.D. Clarke (eds) Cool-water carbonates. SEPM Special Publication 56, pp. 142-162.

Freiwald, A., Hühnerbach, V., Lindberg, B., Wilson, J.B. and Campbell, J., 2002. The Sula Reef complex, Norwegian Shelf. Facies, 47: 179-200.

Freiwald, A., Wilson, J.B. \& Henrich, R., 1999. Grounding Pleistocene icebergs shape recent deep-water coral reefs. Sedimentary Geology, 125: 1-8.

Freiwald, A. \& Shiboard Party (2002b). RV Poseidon cruise 292, 86 pp

Grehan, A.J., Wilson, M., Guinan, J., O’Riordan, J., Molnar, L., Omerdic, E., Ullgren, J., Le Guilloux, E, Toal, D. \& Brown, C. (2006). ROV investigations of cold-water coral habitats along the Porcupine Bank margin, west coast of Ireland. GeoHAB $7^{\text {th }}$ International Symposium (Marine Geological Habitat Mapping), Edinburgh, Scotland, May 2006.

Henriet, J.P., De Mol, B., Pillen, S., Vanneste, M., van Rooij, D., Versteeg, W., Croker, P.F., Shannon, P.M., Unnithan, V., Bouriak, S., Chachkine, P. \& the Porcupine Belgica 97 Shipboard Party , 1998. Gas hydrate crystals may help build coral reefs. Nature, 391, 648-649.

Henriet, J.P., De Mol, B., Vanneste, M., Huvenne, V. \& van Rooij, D. (2001). Carbonate mounds and slope failures in the Porcupine Basin: a development model involving past fluid venting. In: Shannon, P.M., Haughton, P.D.W. and Corcoran, D.V. (eds). The Petroleum Exploration of Ireland's Offshore Basins. Geol. Soc. London Spec. Publ., 188, 375-383. 
Henriet, J. P., Van Rooij, D., Huvenne, V., De Mol, B. \& Guidard, S. 2003. Mounds and sediment drift in the Porcupine Basin, West of Ireland. In J. Mienert, P. Weaver (Eds) European Margin Sediment Dynamics: Side - Scan Sonar and Seismic Images. Springer-Verlag.

Hovland, M. (1990). Do carbonate reefs form due to fluid seepage? Terra Nova, 2, 8-18.

Hovland, M., 1992. Hydrocarbon seepage in northern marine waters - their occurrence and effects. Palaios, 7, 376-382.

Hovland, M., Croker, P.F. \& Martin, M., 1994. Fault-associated seabed mounds (carbonate knolls?) off western Ireland and north-west Australia, Marine and Petroleum Geology, 11, (2), 232-246.

Hovland, M., Mortensen, P.B., Brattegard, T., Strass, P. \& Rokoengen, K., 1998. Ahermatypic coral banks off mid-Norway: evidence for a link with seepage of light hydrocarbons. Palaios, 13: 189-200.

Hovland, M. \& Risk, M. (2003). Do Norwegian deep-water coral reefs rely on fluid seepage? Marine Geology, 198, 83-96.

Hovland, M. \& Thomsen, E., 1989. Hydrocarbon-based communities in the North Sea? Sarsia, 74, 29-42.

Hovland, M. \& Thomsen, E., 1997. Cold-water corals - are they hydrocarbon seep related?- Marine Geology, 137: 159-164.

Hovland, M. (2005). Pockmark-associated coral reefs at the Kristin field off Mid-Norway. In: A. Freiwald \& J.M. Roberts (eds). Cold-water corals and Ecosystems, Springer-Verlag, Berlin, p.623-632.

Huvenne, V.A.I., W.R. Bailey, P.M. Shannon, J. Naeth, R. Di Primio, J.P. Henriet, B. Horsfield, H. de Haas, A. Wheeler, K. Olu-Le Roy (this volume) The Magellan mound province in the Porcupine Basin. International Journal of Earth Science.

Huvenne, V.A.I., Beyer, A., de Haas, H., Dekindt, K., Henriet, J.P., Kozachenko, M., Olu-Le Roy, K., Wheeler, A. \& the TOBI/Pelagia 197 and CARACOLE cruise participants (2005). The seabed appearance of different coral bank provinces in the Porcupine Seabight, NE Atlantic: results from sidescan sonar and ROV seabed mapping. In: A. Freiwald \& J.M. Roberts (eds). Cold-water corals and Ecosystems, Springer-Verlag, 535-569

Huvenne, V. A. I., Blondel, P. \& Henriet, J.-P., 2002. Textural analyses of sidescan sonar imagery from two mound provinces in the Porcupine Seabight. Marine Geology, 189, 323-341.

Huvenne, V.A.I., De Mol, B. \& Henriet, J.P. (2003). A 3D seismic study of the morphology and spatial distribution of buried coral banks in the Porcupine Basin, SW of Ireland, Marine Geology, 189, 323-341

Jonsson LG, Nilsson PG, Floruta F, Lundälv T (2004) Distributional patterns of macro- and megafauna associated with a reef of the cold-water coral Lophelia pertusa on the Swedish west coast. Marine Ecology Progress Series 284: 163-171.

Kenyon, N.H., Akhmetzhanov, A.M., Wheeler, A.J., van Weering, T.C.E., de Haas, H. \& Ivanov, M.K., 2003. Giant carbonate mud mounds in the southern Rockall Trough. Marine Geology, 195, 5-30.

Kenyon, N.H., Ivanov, M.K. \& Akhmetzhanov, A.M., Eds., 1998. Cold water carbonate mounds and sediment transport on the Northeast Atlantic Margin. IOC Technical Series. Paris, UNESCO, 178pp.

Klages, M., Thiede, J. \& Foucher, J.-P., 2004. The Expedition ARKTIS XIX/3 of the Research Vessel POLARSTERN in 2003. Reports of Legs 3a, 3b and 3c. Reports on Polar and Marine Research, 488.355pp.

Kiriakoulakis, K., Bett, B.J. \& Wolff, G.A. (2001). Biogeochemistry of the Darwin Mounds - preliminary results. European Union of Geosciences XI. Cambridge Publications, Strasbourg, p.751.

Le Bas, T. \& Hühnerbach, V., 1999. P.R.I.S.M. Processing of Remotely-sensed Imagery for Seafloor Mapping Operators Manual Version 3.1. Southampton Oceanography Centre, UK.

Le Danois, E., 1948. Les profondeurs de la Mer. Payot, Paris, 1-303.

Lien, R., 1983. Iceberg scouring on the Norwegian continental shelf.- Proc. Annual Offshore Technology Conference, Dallas, Texas, 15: 41-45.

Lindberg, B. \& Mienert, J. 2005. Sedimentology and geochemical environment of the Fugløy Reef off northern Norway. Cold-water Corals and Ecosystems. ( A. Freiwald \& J.M. Roberts, eds). Springer-Verlag, Berlin Heidelberg, pp.633650.

Lindberg, B., Berndt, C. \& Mienert, J., this volume. The Fugløy Reefs on the Norwegian-Barents Continental Margin: Coldwater Corals at $70^{\circ} \mathrm{N}$, their acoustic signature, geologic, geomorphologic and oceanographic setting

Masson, D.G., Bett, B.J., Billett, D.S.M., Jacobs, C.L., Wheeler, A.J. \& Wynn, R.B., 2003. The origin of deep-water, coraltopped mounds in the northern Rockall Trough, Northeast Atlantic. Marine Geology, 192, 215-237.

Mienis, F., de Haas, H, Shipboard Scientific Party, 2004. Report of cruise Moundforce 2004. The distribution, morphology, sedimentology and watermass characteristics of and around mounds in the Gulf og Cadiz and at the SW Rockall Trough margin. Unpublished Report, NIOZ, 100 pp

Mienis, F., van Weering, T., de Haas, H., de Stigter, H., Huvenne, V. \& Wheeler. A. (in press) High-resolution TOBI images and seismic profiles of a carbonate mound province at the SW Rockall Trough Margin, NE Atlantic, Marine Geology.

Mikkelsen, N., Erlenkeuser, H., Killingley, J.S. \& Berger, W.H. (1982): Norwegian corals: radiocarbon and stable isotopes in Lophelia pertusa.- Boreas, 11: 163-171.

Mortensen, P.B., Hovland, M., Brattegard, T. \& Farestveit, R. (1995): Deep water bioherms of the scleractinian coral Lophelia pertusa (L.) at $64^{\circ} \mathrm{N}$ on the Norwegian shelf: structure and associated megafauna.- Sarsia, 80: 145-158.

Mortensen, P.B., Hovland, M.T., Fossa, J.H. \& Furevik, D.M. (2001): Distribution, abundance and size of Lophelia pertusa coral reefs in mid-Norway in relation to seabed characteristics.- Journal of the Marine Biological Association of the United Kingdom, 81: 581-597.

Naeth, J., di Primio, R., Horsfield, B., Schaefer, R.G., Shannon, P.M., Bailey, W.R. \& Henriet, J.P., this volume. From the Connemara Oil Field to the Belgica Mound Province: modelling hydrocarbon migration in the Porcupine Basin, offshore Ireland.

Olu-Le Roy, K., Caprais, J-C., Crassous, P., Dejonghe, E., Eardley, D., Freiwald, A., Galeron, J., Grehan, A., Henriet, J-P., Huvenne, V., Lorance, P., Noel, P., Opderbecke, J., Pitout, C., Sibuet, M., Unnithan, V., Vacelet, J., Van Weering, T., 
Wheeler, A. \& Zibrowius, H., 2002. CARACOLE Cruise Report. 30/07/2001 (Cobh) - 15/08/2001 (Foynes) N/O L'Atalante \& ROV VICTOR, Vols. 1 \& 2. Unpublished Report, IFREMER, Brest.

O’Reilly, B.M., Readman, P.W., Shannon, P.M. \& Jacob, A.W.B. (2003). A model for the development of a carbonate mound population in the Rockall Trough based on deep-towed sidescan sonar data. Marine Geology, 198, 55-66.

O’Reilly, B.M. \& Readman, P.W. (2004). Cold-water coral mounds: Evidence for early Holocene climate change and slope failure. Geophysical Research Letters, 13, xxx

Roberts, J.M., A.J. Wheeler, A. Freiwald (2006). Reefs of the deep: the biology and geology of cold-water coral ecosystems, Science, 312, 543-547

Rogers, A.D. (1999). The biology of Lophelia pertusa (Linnaeus 1758) and other deep-water reef-forming corals and impacts from human activity. International Review of Hydrobiology, 84, 315-410.

Rokoengen, K. \& Østmo, S.R., 1985. Shallow geology off Fedje, western Norway.- IKU Report, 24.1459/01/85.

Rüggeberg, A., Dullo, C., Dorschel, B. \& Hebbeln, D., this volume. Environmental changes and growth history of Propeller Mound, Porcupine Seabight: Evidence from benthic foraminiferal assemblages

Scoffin, T.P., Alexandersson, E.T., Bowes, G.E., Clokie, J.J., Farrow, G.E. \& Milliman, J.D., 1980. Recent, temperate, subphotic, carbonate sedimentation: Rockall Bank, northeast Atlantic. Sedimentary Geology, 60, 125-134.

Swennen, R., Cronin, B., Ivanov, M., Kozlova, E., Wheeler, A.J., Akhmetzhanov, A., Sautkin, A., Van Rooij, D., Zaragosi, S., Mazurenko, L., Degryse, C., Sumida, P., Satur, N., Kennedy, R., Akhmanov, G., Belen'kaya, I., Pillen, S., Naumov, Y., Stadnitskaya, A., de Mol, B., Balashova, A. \& Saprykina, A. (1998). Bottom sampling results. In: Kenyon, N.H., Ivanov, M.K. and Akhmetzhanov, A.M. (Eds.). Cold water carbonate mounds and sediment transport on the Northeast Atlantic margin, UNESCO, Paris, Intergovernmental Oceanographic Commission technical series, 52, 59-97.

Taviani, M., Freiwald, A. \& Zibrowius, H. (2005). Deep coral growth in the Mediterranean Sea: an overview. In: A. Freiwald \& J.M. Roberts (eds). Cold-water corals and Ecosystems, Springer-Verlag, 137-156.

Teichert, C., 1958. Cold- and deep-water coral banks, The Bulletin of the American Association of Petroleum Geololgists, 42, 1064-1082.

Unnithan, V., 2001. Geological and Sedimentological Analysis of Sidescan Sonar Data in the Rockall Trough and Porcupine Seabight, West of Ireland. Unpublished PhD. Thesis. National University of Ireland, Dublin, 360 pp.

Van Rooij, D., Blamart, D. \& Unnithan, V. (2001). Cruise Report MD 123 - Géosciences : Leg 2, part Geomound, 67 pp

Van Rooij, D., De Mol, B., Huvenne, V., Ivanov, M. \& Henriet, J.-P., 2003. Seismic evidence of current-controlled sedimentation in the Belgica mound province, upper Porcupine slope, southwest of Ireland. Marine Geology, 195, 31-53.

Van Rooij, D., D. Blamart, T. Richter, A. Wheeler, M. Kozachenko \& J.-P. Henriet, this volume. Quaternary drift sediment dynamics in the Belgica mound province, Porcupine Seabight: a multidisciplinary approach.

van Weering, T.C.E., De Haas, H., Akhmetzanov, A.M. \& Kenyon, N.H., 2003. Giant carbonate mounds along the Porcupine and SW Rockall Trough Margins. In J. Mienert, P. Weaver (Eds) European Margin Sediment Dynamics: Side - Scan Sonar and Seismic Images. Springer-Verlag, p.211-216.

van Weering, T.C.E. and Shipboard Scientific Party, 1999. Shipboard report cruise RV pelagia 64PE143. A survey of carbonate and mud mounds of the Porcupine Bight and S Rockall Trough margins. Cruise report, NIOZ, 82 pp.

Vorren, T.O., Hald, M., Edvardsen, M. \& Lind-Hansen, O.W., 1983. Glacigenic sediments and sedimentary environments on continental shelves: General principles with a case study from the Norwegian shelf. Glacial Deposits in North-West Europe. J. Ehlers. Rotterdam, A. A. Balkema: 61-73.

Wheeler, A.J., Beck, T., Thiede, J., Klages, M., Grehan, A. Monteys, F.X. \& Polarstern ARK XIX/3a Shipboard Party (2005a). Deep-water cold-water coral carbonate mounds on the Porcupine Bank, Irish margin: preliminary results from Polarstern ARK-XIX/3a ROV cruise. In: A. Freiwald \& J.M. Roberts (eds). Cold-water corals and Ecosystems, Springer-Verlag, Berlin, p.323-333.

Wheeler, A.J., B.J. Bett, D.S.M. Billett, D. G. Masson \& D. Mayor (2005b). The Impact of Demersal Trawling on NE Atlantic Deep-water Coral Habitats: the case of the Darwin Mounds, UK. In: J. Thomas \& P. Barnes (eds) Benthic Habitats and the Effects of Fishing, America Fisheries Society, Symposium 41, Bethesda, Maryland, USA., p.807-818.

Wheeler, A.J., Kozachenko, M., Beyer, A., Foubert, A., Huvenne, V.A.I., Klages, M., Masson, D.G., Olu-Le Roy, K. \& Thiede, J. (2005c). Sedimentary processes and carbonate mounds in the Belgica mound province, Porcupine Seabight, NE Atlantic. . In: A. Freiwald \& J.M. Roberts (eds). Cold-water corals and Ecosystems, Springer-Verlag, Berlin. p. 533564.

Wheeler, A.J., Kozachenko, M., Masson, D.G. \& Huvenne, V.A.I. (subm.). The influence of benthic sediment transport on cold-water coral bank morphology and growth: the example of the Darwin Mounds, NE Atlantic. Sedimentology

Wheeler, A. \& TTR9 Shipboard Scientific Party, 2000. Seabed geotechnical and biogeochemical survey in the eastern Rockall Trough. In: N.H. Kenyon, M.K .Ivanov, A.M. Akhetzhanov \& G.G. Akhmanov (eds) Multidisciplinary Study of Geological Processes on the North East Atlantic and Western Mediterranean Margins: Preliminary Results of Geological and Geophysical Investigations during the TTR-9 cruise of R/V Professor Logachev June-July, 1999. Intergovernmental Oceanography Commission Technical Series, 56, 35-41.

White, M., Mohn, C., de Stigter, H \& Mottram, G. (2005). Deep-water coral development as a function of hydrodynamics and surface productivity around submarine banks of the Rockall Trough, NE Atlantic. In: A. Freiwald \& J.M. Roberts (eds). Cold-water corals and Ecosystems, Springer-Verlag, Berlin. p. 503-514.

Wilson, J.B., 1979a. The distribution of the coral Lophelia pertusa (L.) [L. prolifera (Pallas)] in the north-east Atlantic. Journal of the Marine Biological Association of the United Kingdom, 59, 149-164.

Wilson, J.B., 1979b. 'Patch' development of the deep-water coral Lophelia pertusa (L.) on Rockall Bank. Journal of the Marine Biological Association of the United Kingdom, 59, 165-177. 
16 Wheeler, A.J.P1P, Beyer, A.P2P, Freiwald, A.P3P, de Haas, H.P4P, Huvenne, V.A.I.P5P, Kozachenko, M.P1P,Olu-Le Roy, K.P6P \& Opderbecke, J.P7P

Wisshak M, Gektidis M, Freiwald A, Lundälv T (2005) Bioerosion along a bathymetric gradient in a cold-temperate setting (Kosterfjord, SW Sweden): an experimental study. Facies 51: 93-117.

Zibrowius, H., 1980. Les scléractiniaires de la Méditerranee et de l’Atlantique nord-oriental. Monaco, Mémoires de l'Ínstit Oceanographique, 11, 284p. 


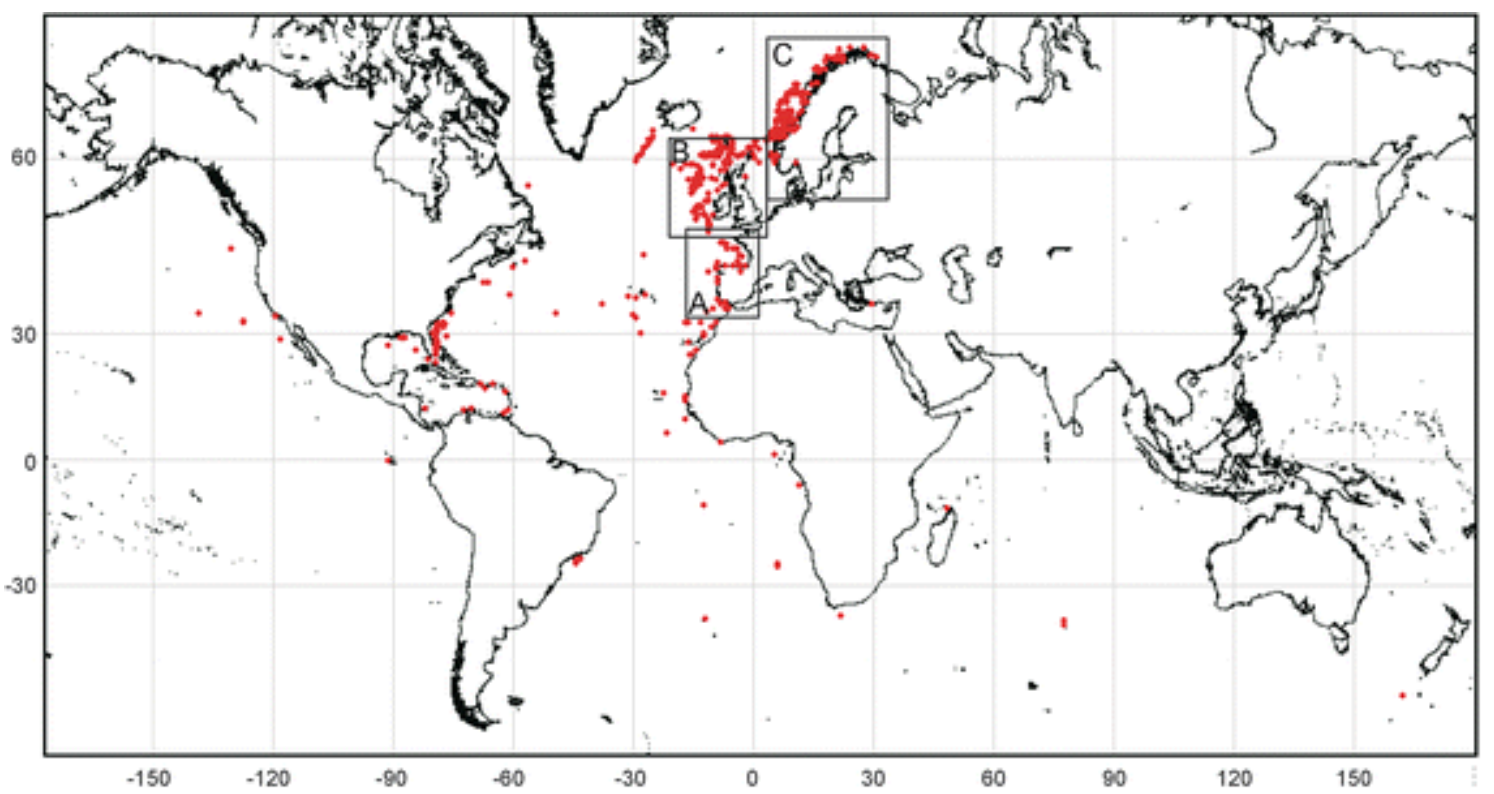

Figure 1: Global distributions of documented Lophelia pertusa occurrences. Boxes (A, B and C) refer to the location of highlights presented in Figure 2. Bathymetry from GEBCO. 

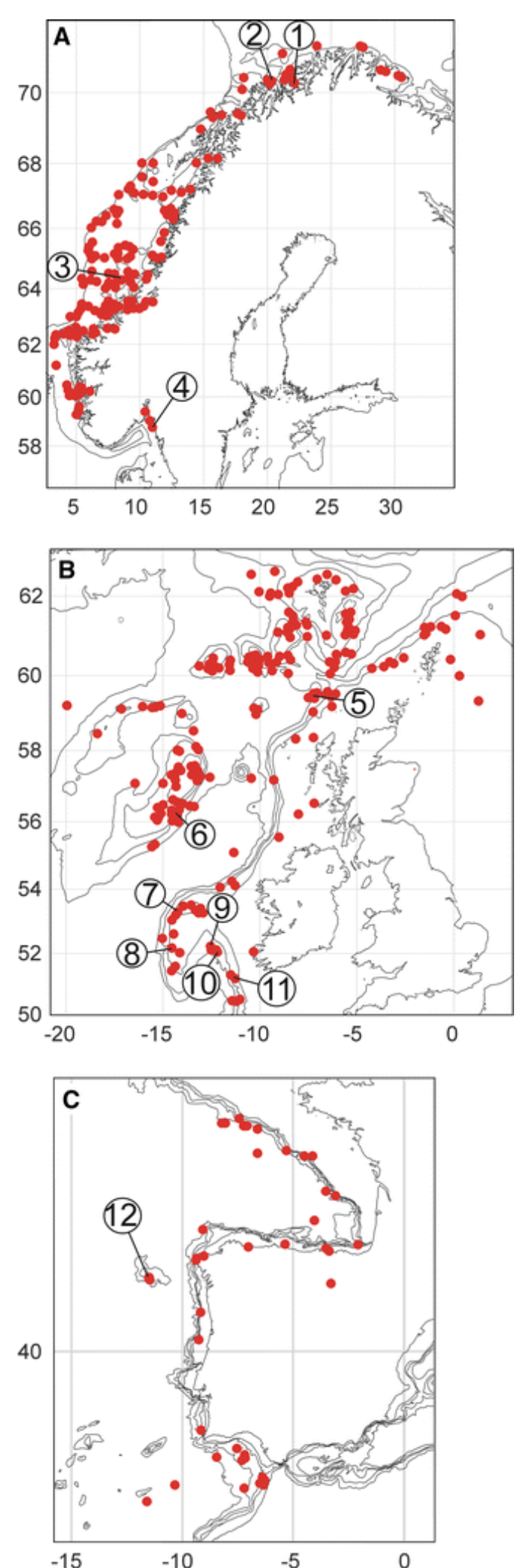

Figure 2. European distribution of documented Lophelia pertusa occurrences: A - Franco/Iberian Margin, B Irish/British/Faraoese margin, and C - Swedish/Norwegian margin. See Figure 1 for location of detailed maps. Bathymetry from GEBCO. The names of confirmed coral mound (as opposed to isolated coral finds) are labelled: 1 - Stjernsund Reef, 2 - Fugløy Reefs, 3- Sula Ridge, 4 - Kosterfjord, 5 - Darwin Mounds, 6 Logachev Mounds, 7 - Pelagia Mounds, 8 - Porcupine Bank Canyon Mounds, 9 - Magellan Mounds, 10 Hovland Mounds, 11 - Belgica Mounds, and 12 - Galicia Bank Thickets. 


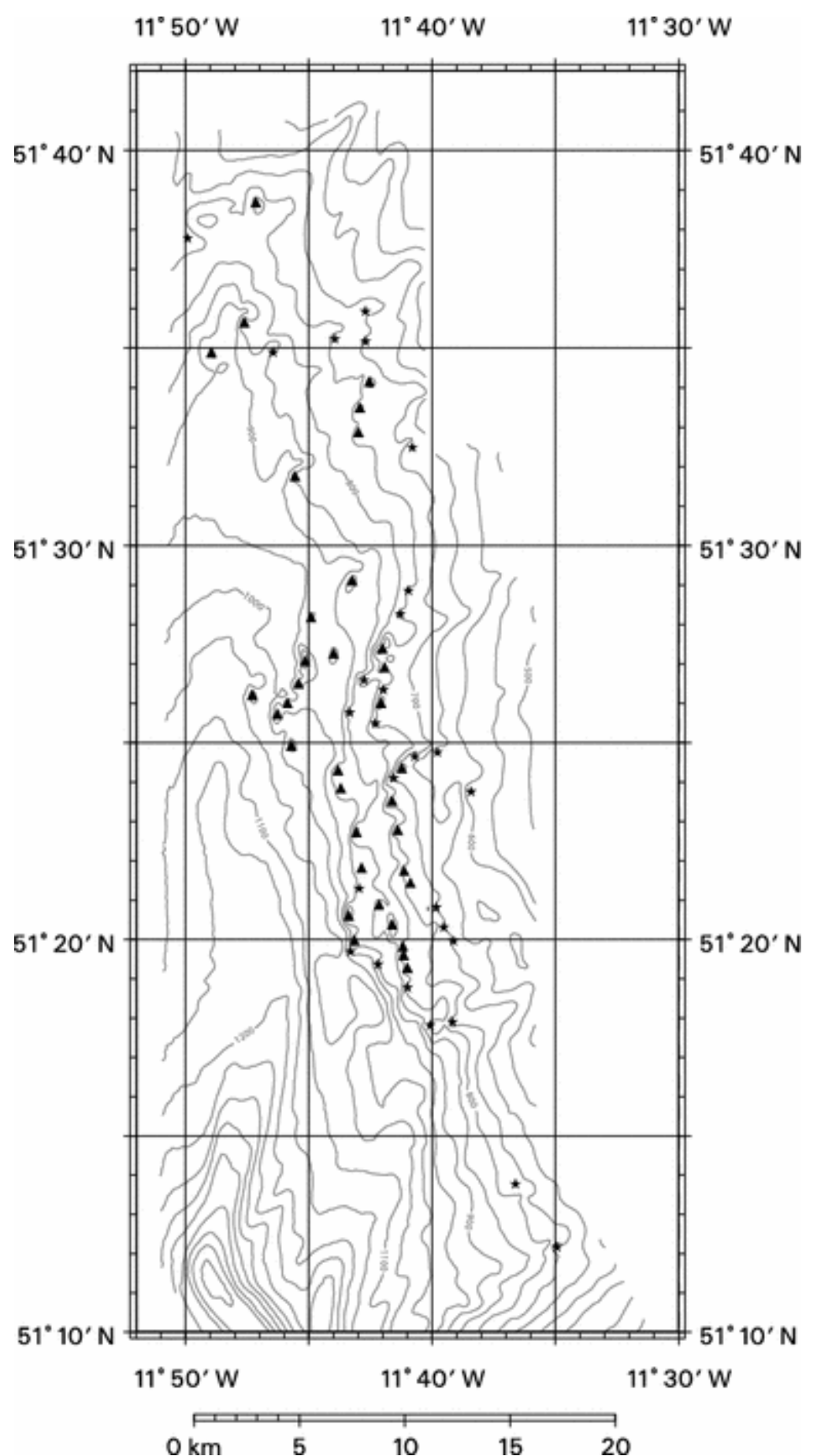

Figure 3: Mound occurrences in the Belgica Mound province. Triangles indicate outcropping mounds. Features identified as buried coral mound are indicated by asterisks. Contours are at $50 \mathrm{~m}$ intervals (from Beyer et al., 2003). 


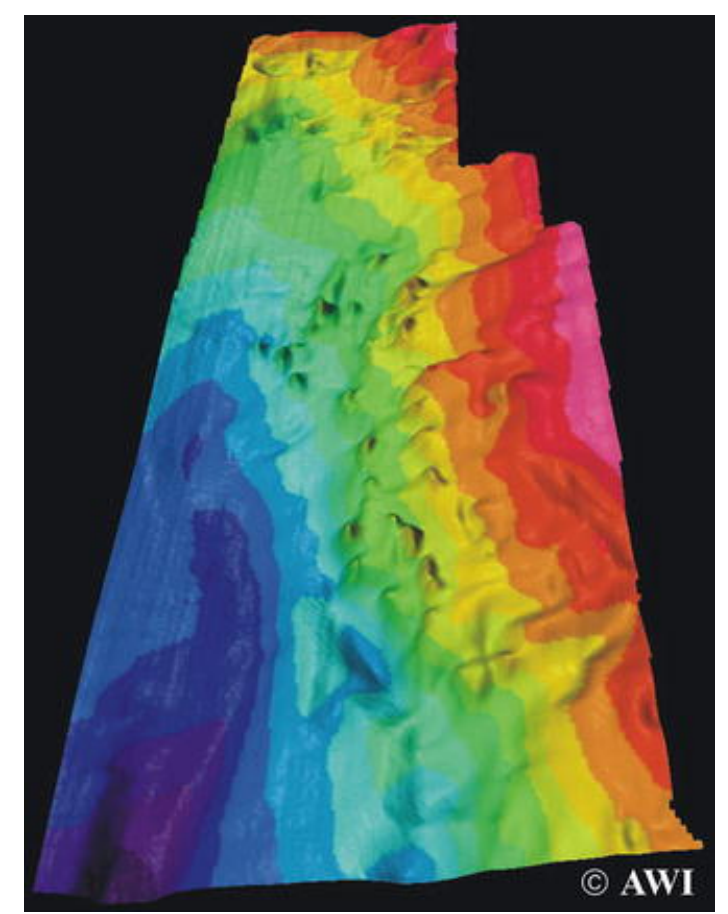

Figure 4.View of Belgica Mound province showing both conical and elongated, ellipsoidal ridge-forms. The eastern, upslope-side of the mounds is often buried by sediments which leads to a terrace-like margin morphology
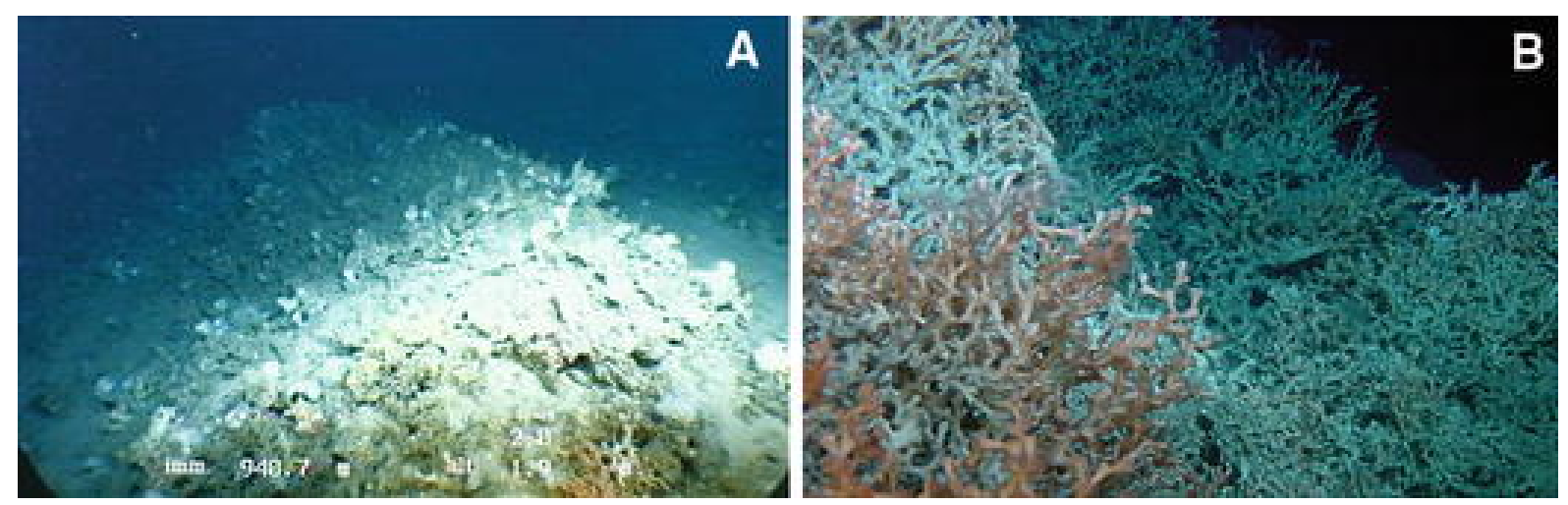

Figure 5: Video still (VICTOR ROV) showing coral banks at (a) the base of the Thérèse Mound where coral colonies trap migrating sands, and (b) the summit of the Thérèse Mound where waveforms are purely biological constructions. 


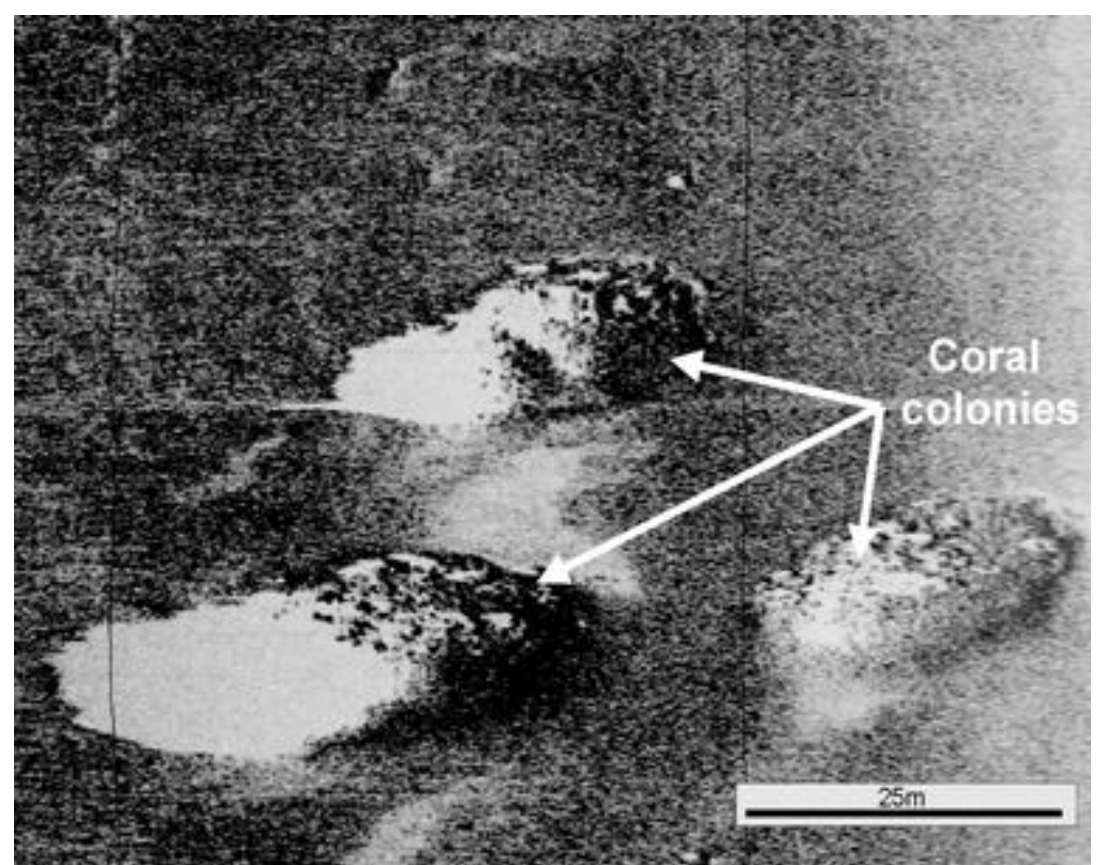

Figure 6: $410 \mathrm{kHz}$ side-scan sonar image of small cold-water coral carbonate mounds (Moira Mounds), acoustic shadows are white.

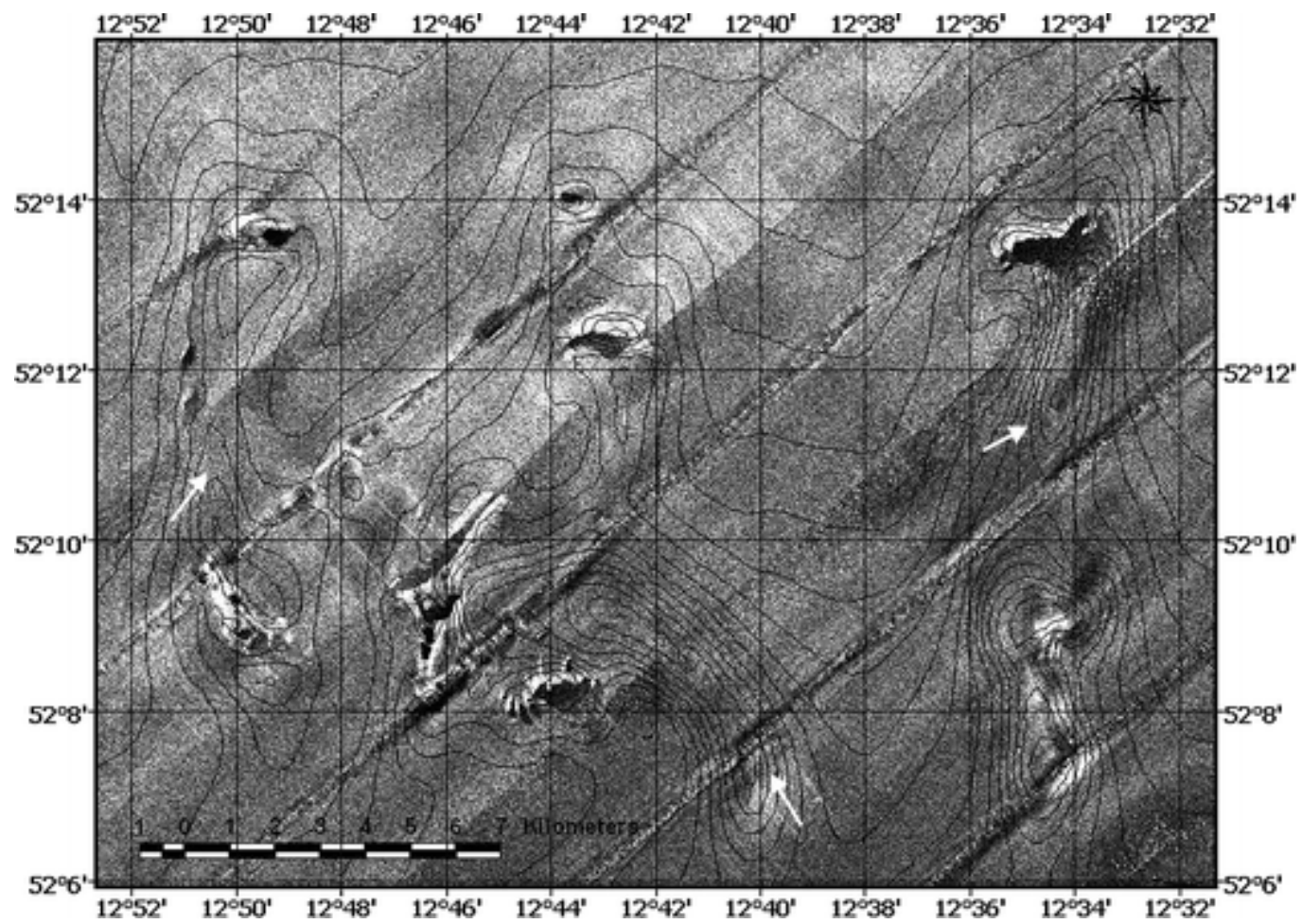

Figure 7: Detail of the central cluster of Hovland mounds from TOBI side-scan sonar imagery (contour interval $20 \mathrm{~m}$ ). White arrows point to blind channels down-current of mounds. Bathymetry data courtesy of the Irish National Seabed Survey, Geological Survey of Ireland 


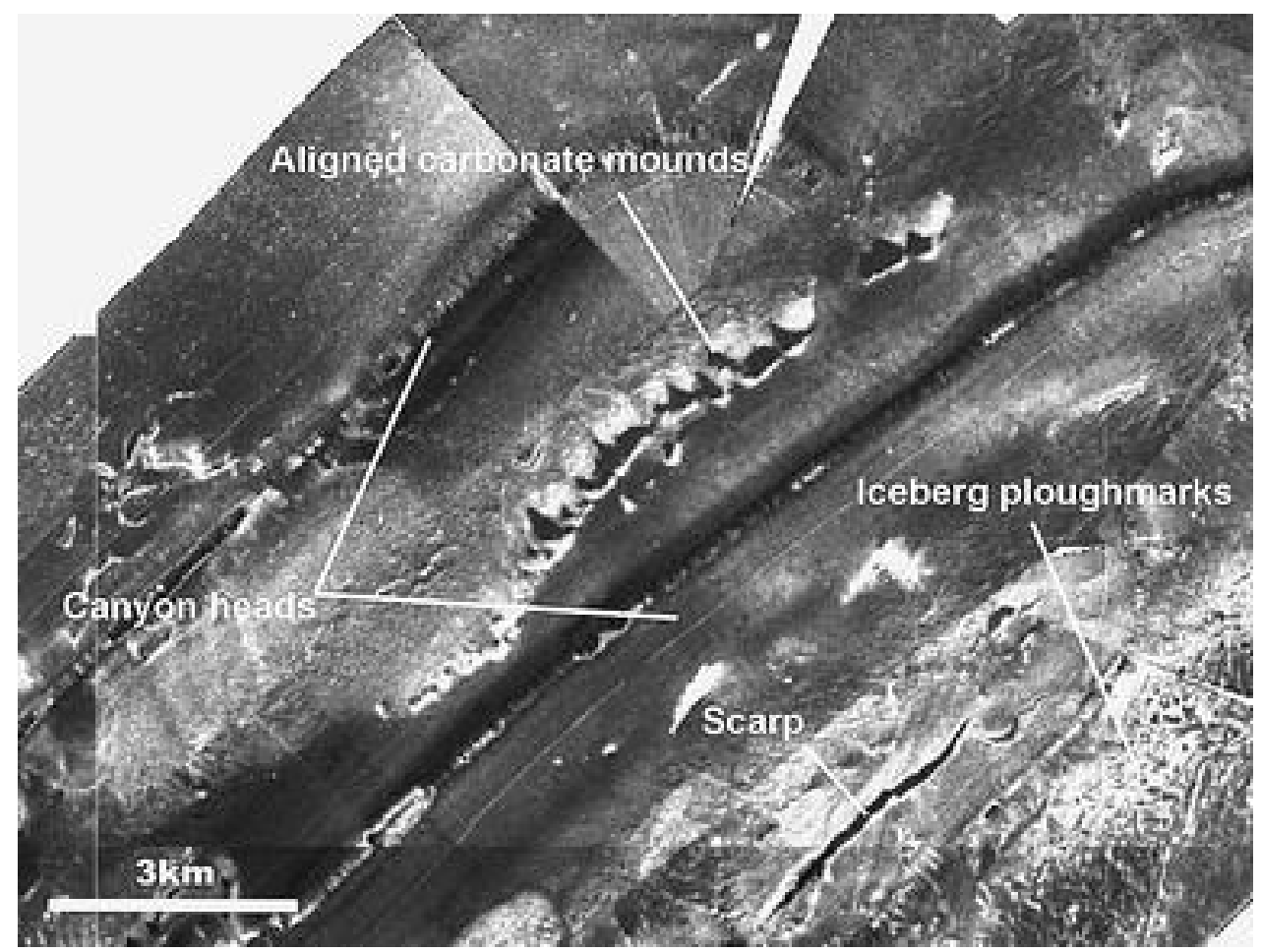

Figure 8: An alignment of Pelagia Mounds along a topographic ridge separating two canyon head feeder systems. An upslope erosional scarp and iceberg plough marks are also imaged. Downslope direction is to the north-west

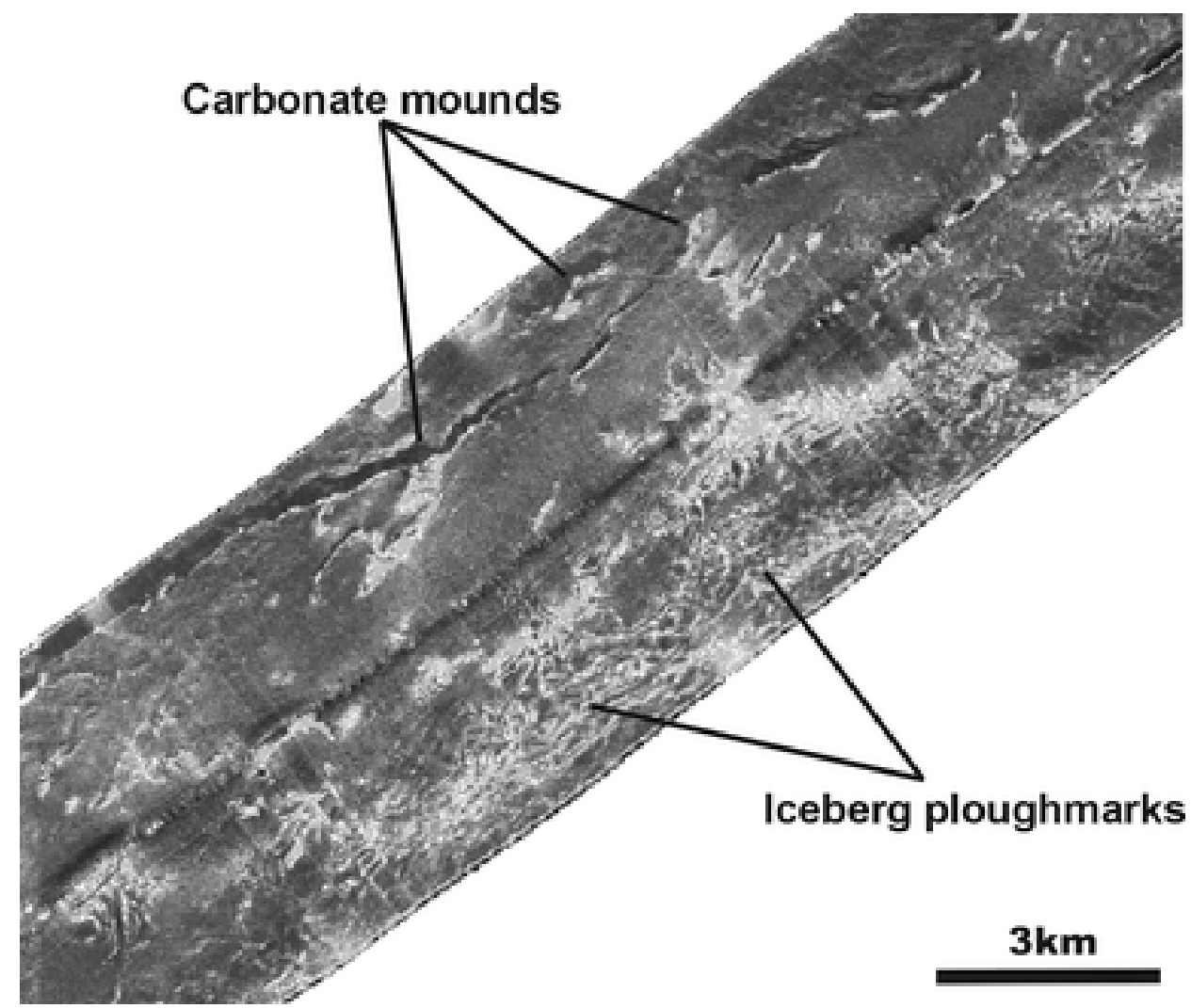

Figure 9: TOBI side-scan sonar image showing scarps with small mound development aligned along the crest and an upslope zone of iceberg plough marks in the Pelagia Mound province. Downslope direction is to the north-west 


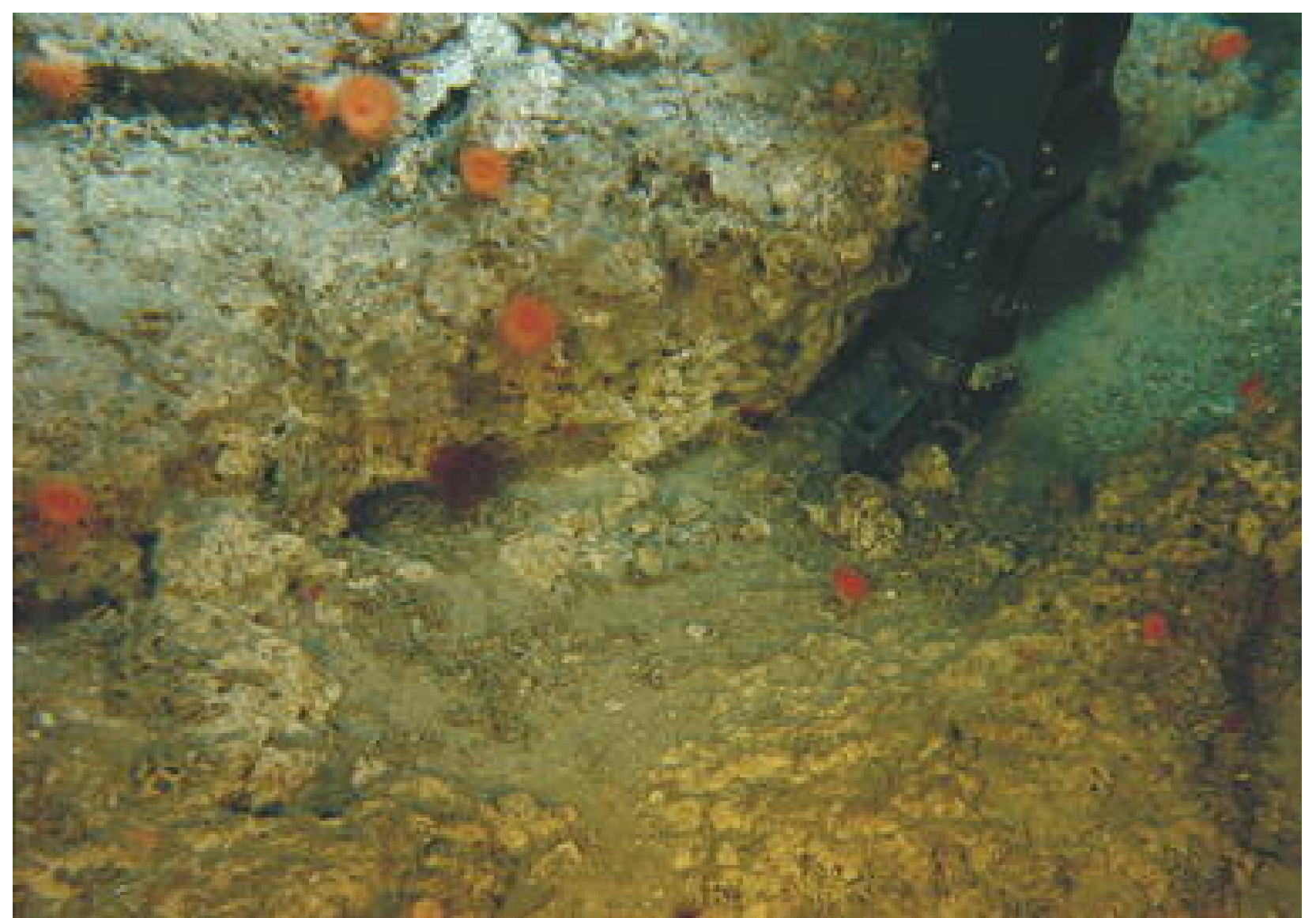

Figure 10. Video still (VICTOR ROV) showing consolidated sediment exposed by seabed erosion offering a suitably hard substrate for colonisation by the solitary cold water coral Desmophyllum cristagalli in the vicinity of the Pelagia Mounds.

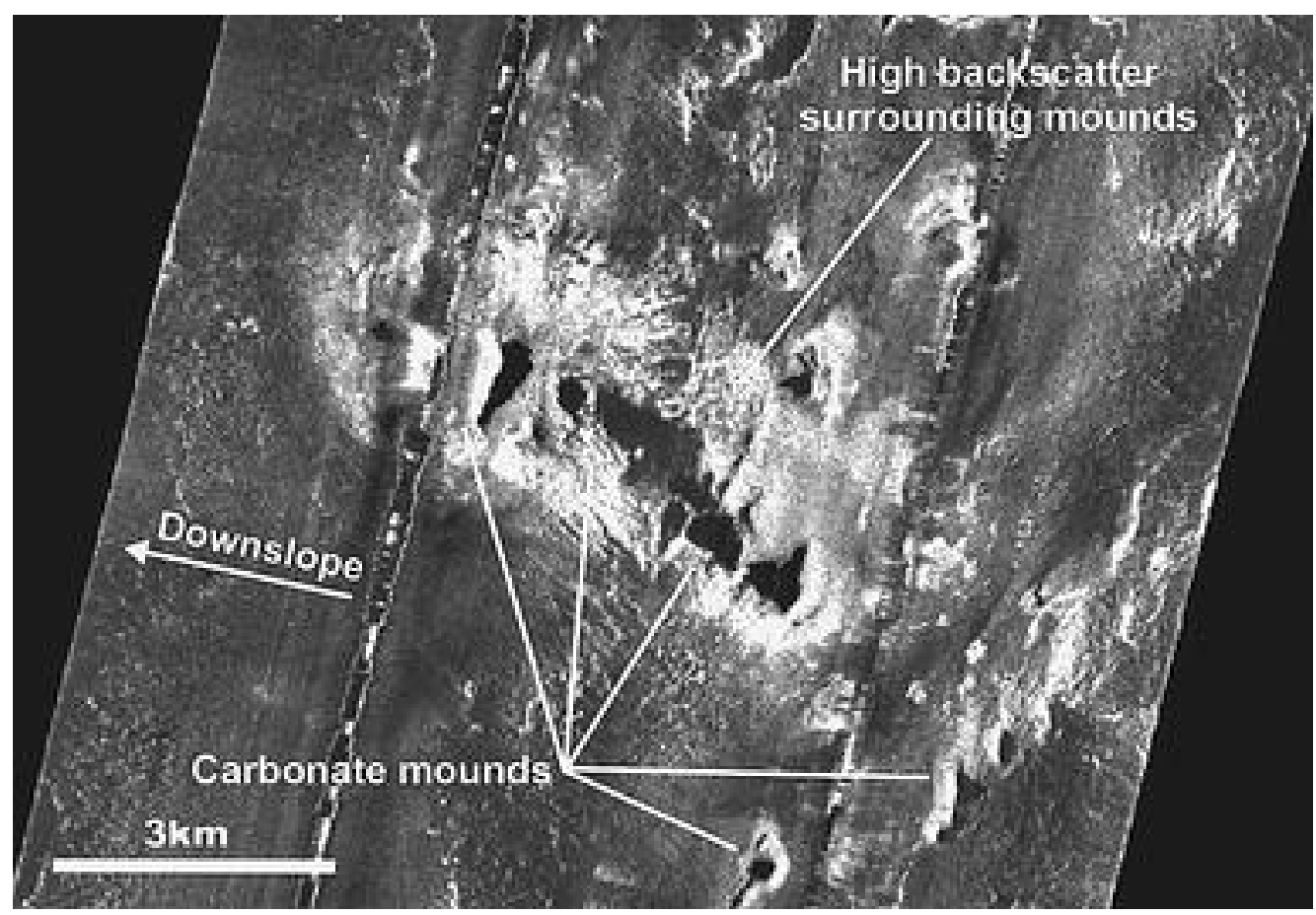

Figure 11: TOBI side-scan sonar image of a cluster of giant cold-water coral carbonate mounds in the Pelagia Mound province, Porcupine Bank. The cluster is aligned downslope and surrounded by high backscatter suggesting off mound coral colonisation or surrounding coarse sediment indicative of an erosive high current regime. 


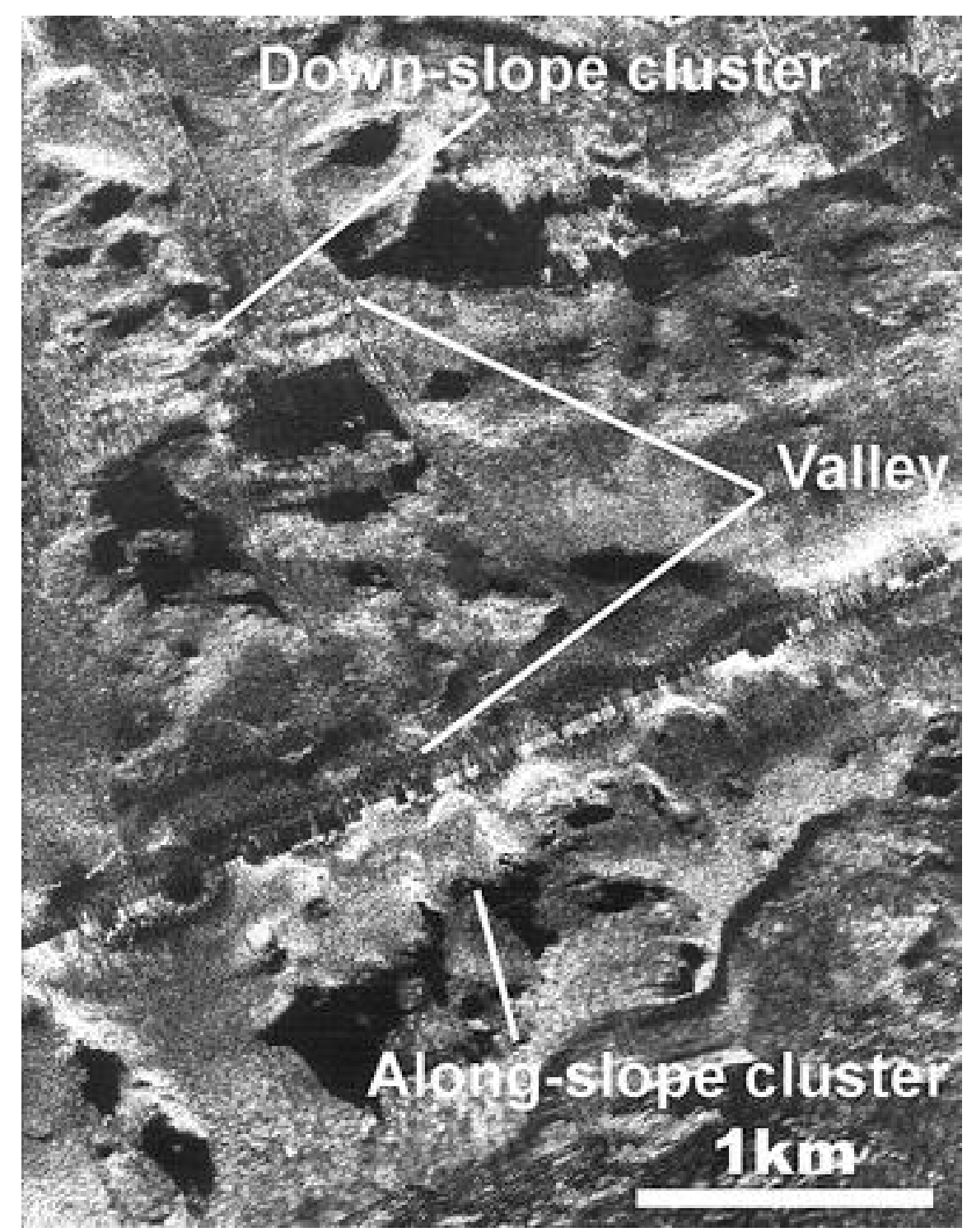

Figure 12: Down-slope and along-slope giant coral mound clusters separated by "valleys" in the Logachev Mound province.

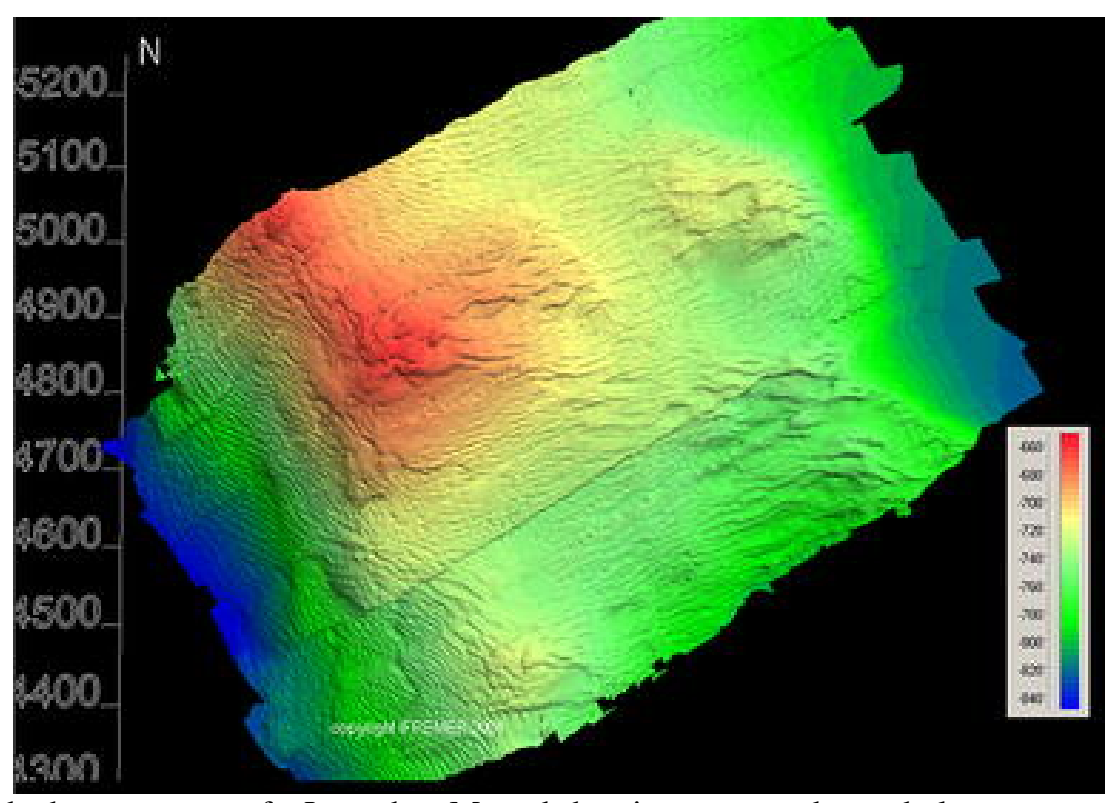

Figure 13. Microbathymetry map of a Logachev Mound showing a terraced morphology. 

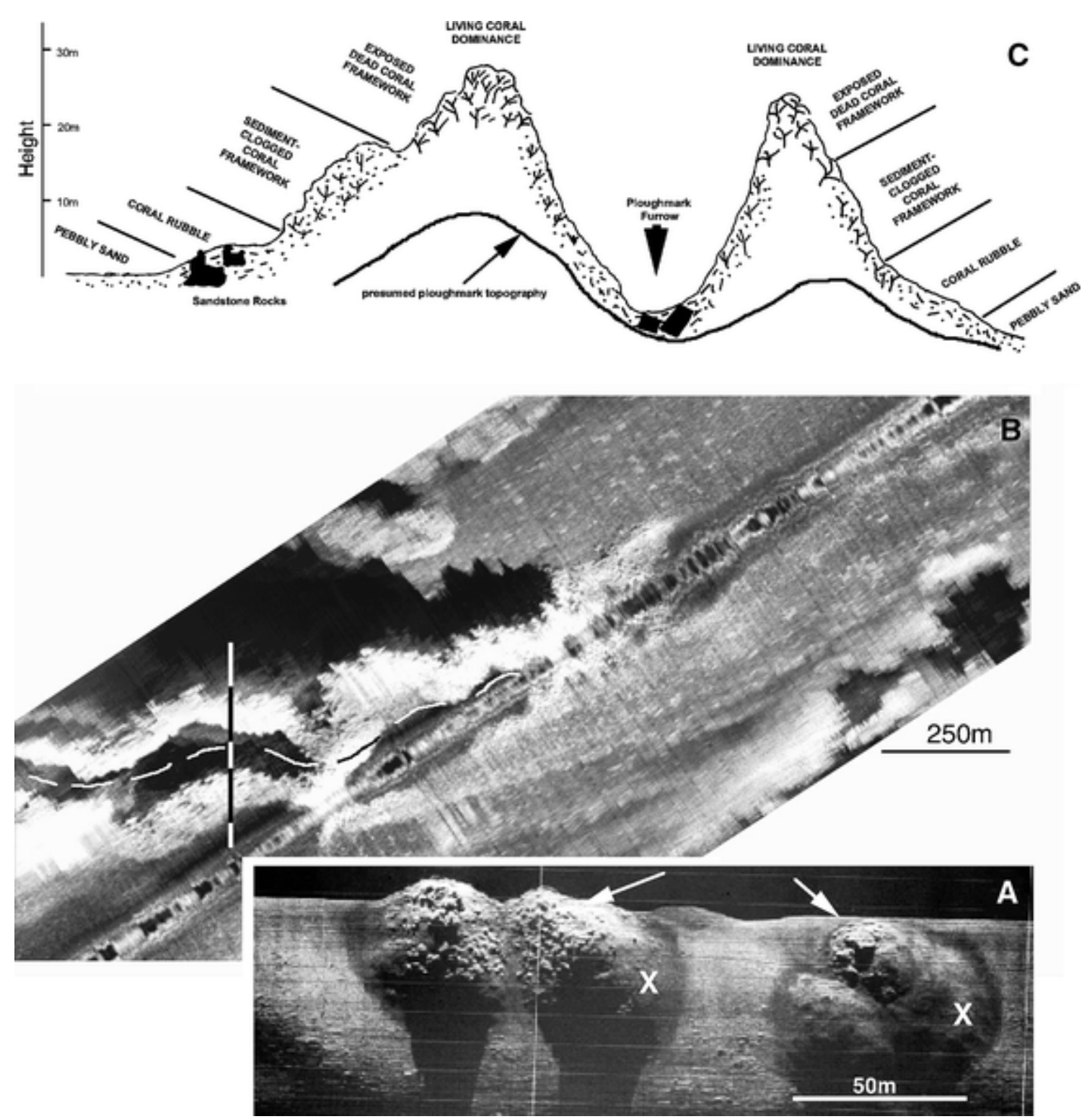

Figure 14: The Sula Reef Complex. (a) small circular Lophelia reefs with the cauliflower backscatter pattern (arrows) indicating the presence of metre-sized hemispheroidal coral colonies. Substantial portions of the reefs show a smooth backscatter signal $(\mathrm{X})$ that represents the coral rubble facies rich in sponges $(375 \mathrm{kHz}-$ Sonograph). (b) A $100 \mathrm{kHz}$ sonograph of a Lophelia reef chain growing along the boulder levees of an iceberg ploughmark (stripled line). The straight line across the ploughmark track is interpreted in $\mathbf{C}$ with the sedimentary facies succession. (c) Sedimentary facies sequence across a Lophelia reef complex (modified from Freiwald et al., 2002). 


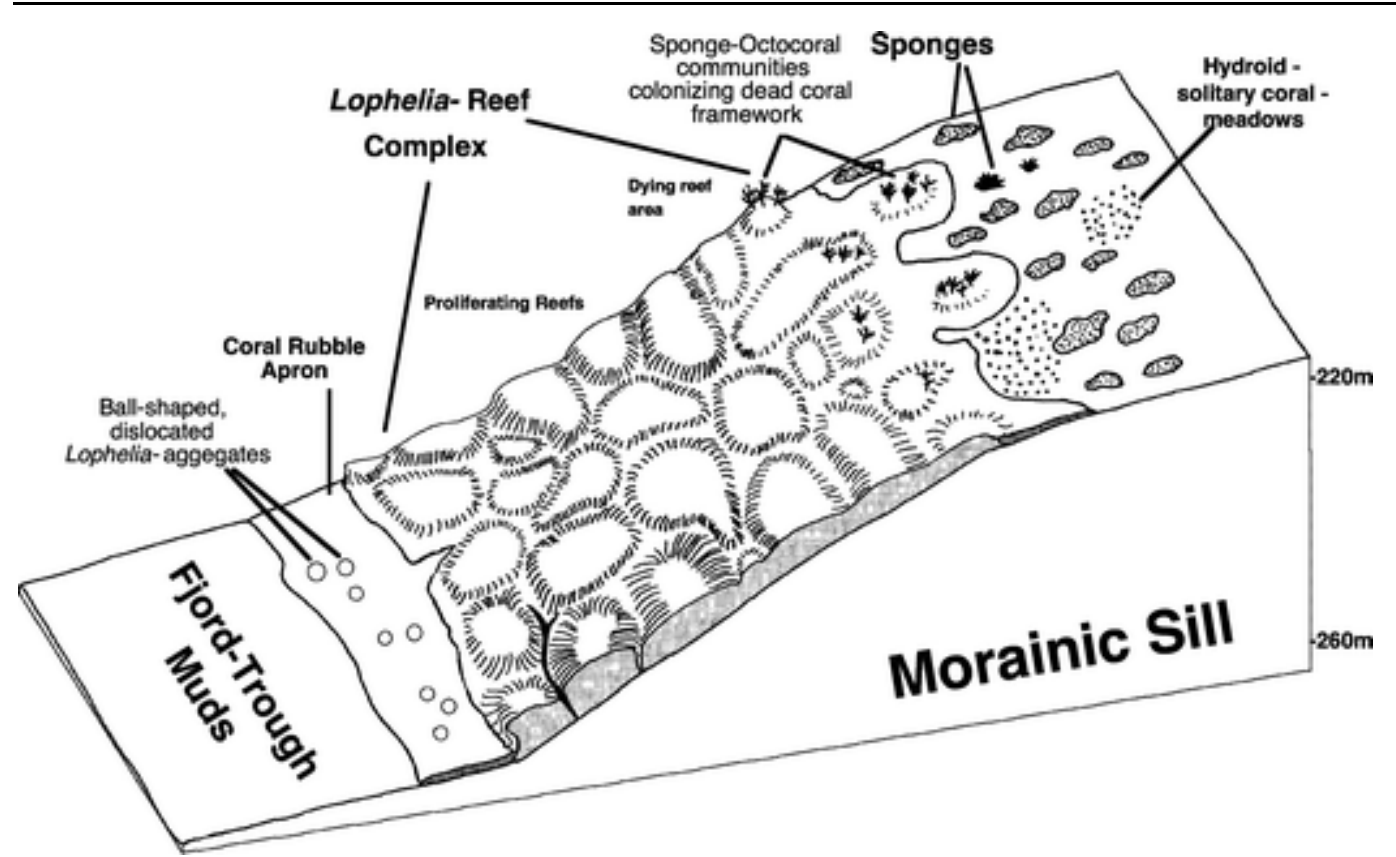

Figure 15. The Stjernsund Reef setting belongs to the northernmost biogeographic occurrence of Lophelia pertusa. Strikingly, the shallowest parts of the sill are colonised by sponges and anemones whereas the flank of the sill is inhabited by the coral reef (modified from Freiwald et al., 1997).
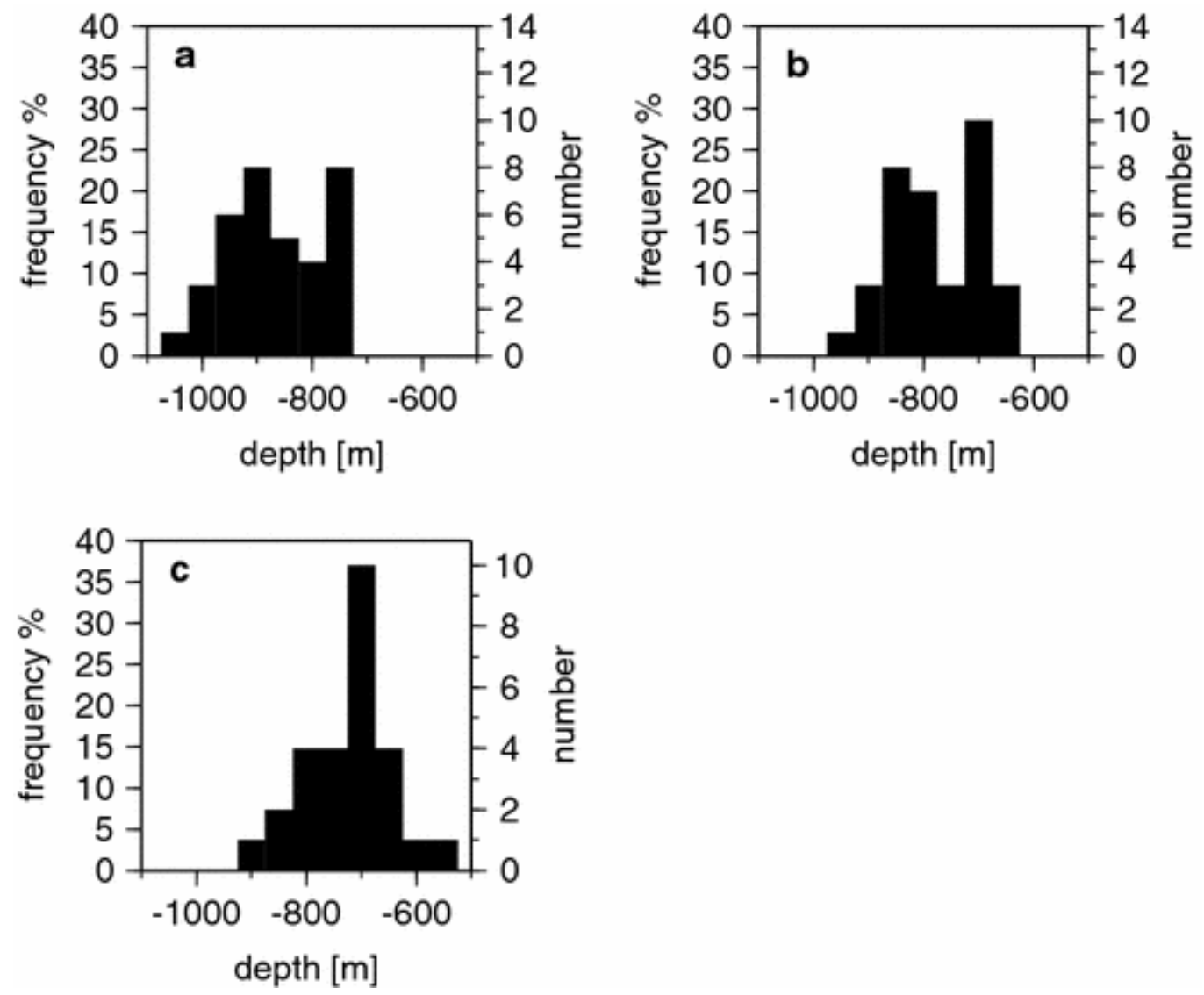

Figure 16: Depth distribution of Belgica Mound (a) bases, (b) mound summits and (c) summits of buried mounds. Two peaks are visible for the mounds accumulating in depth windows that are $100 \mathrm{~m}$ apart. Left scale represents frequency percent, right scale is absolute number of mounds. 

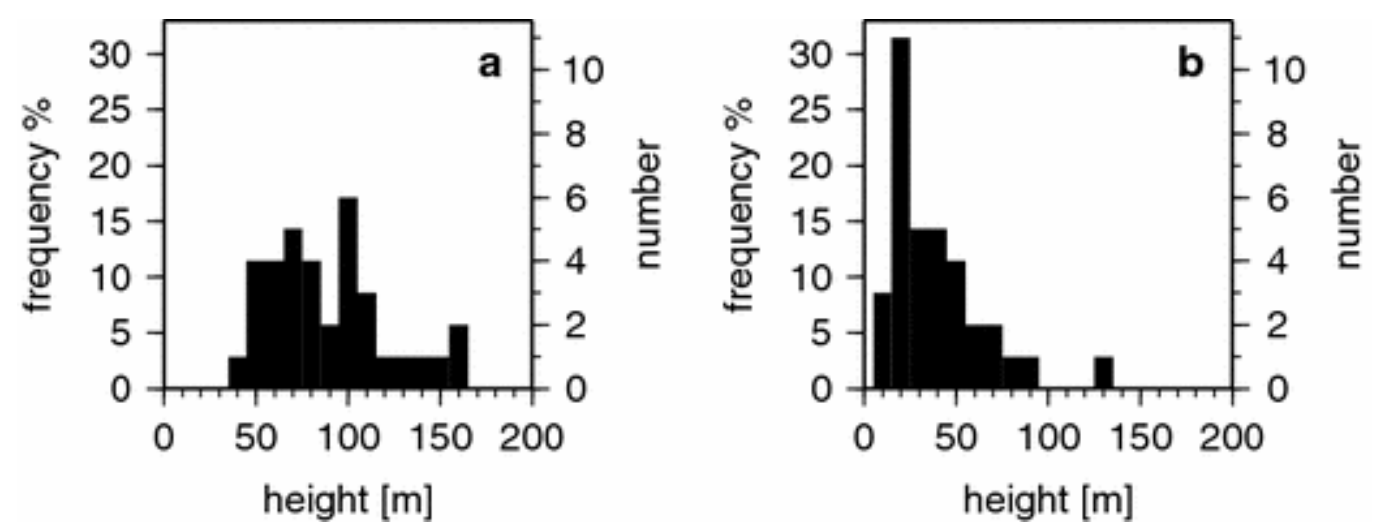

Figure 17: Distribution of the mound heights in the Belgica Mound province: (a) downslope heights of the mounds and (b) upslope heights of the mounds. Left scale represents frequency percent, right scale in absolute number of mounds.
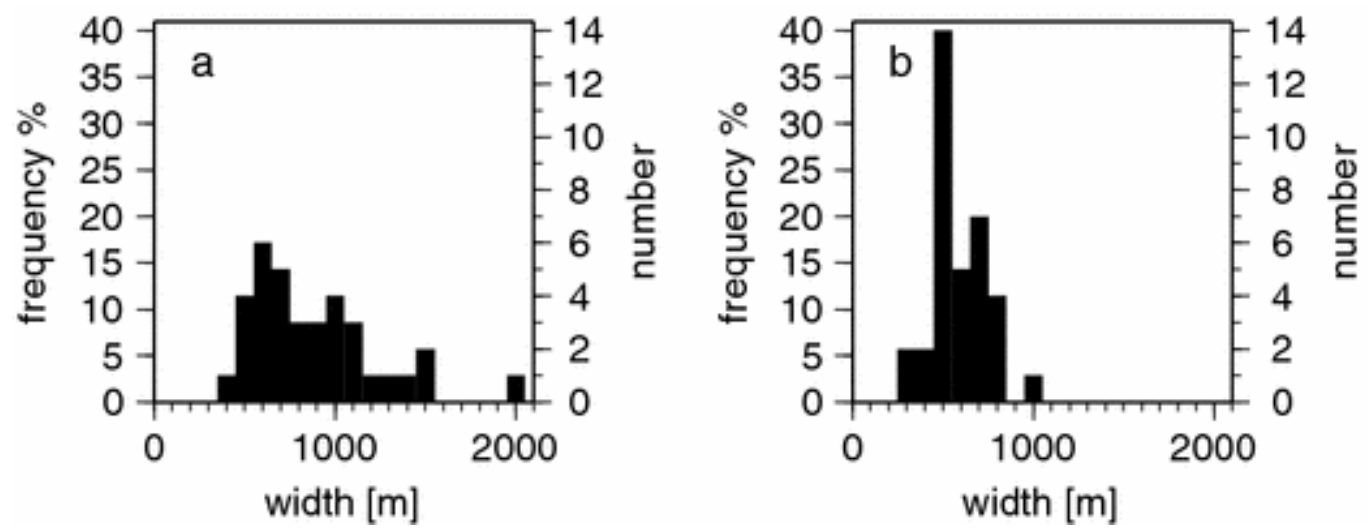

Figure 18: Distribution of the mound widths in the Belgica Mound province: (a) north-south and (b) east-west. Left scale represents frequency percent, right scale in absolute number of mounds. 